\title{
Stres ve Yaratıcı Drama: Üniversite Öğrencileri ile Yapılan Bir Çalışma*
}

\author{
Rezzan Gündoğdu' ${ }^{1}$
}

\section{Ömer Adigüzel ${ }^{2}$}

\begin{tabular}{|c|c|c|}
\hline \multicolumn{2}{|c|}{ Makale Bilgisi } & Öz \\
\hline \multicolumn{2}{|c|}{ DOI: $10.21612 /$ yader.2016.004 } & Bu araştırmanın amacı, stresle baş etme becerisi düşük olan üniversite öğrencilerine \\
\hline \multicolumn{2}{|c|}{ Makale Geçmişi } & incelenmesidir. Araştırma zaylf deneysel desenlerden, "tek grup öntest - sontest \\
\hline Geliş tarihi & 26.02 .2016 & desen" deneme modeline göre geliştirilmiş yar deneysel bir çalışmadır. Aksaray \\
\hline Düzeltme & 14.04.2016 & $\begin{array}{l}\text { Üniversitesi Eğitim Fakültesi ögrencilerinden seçilen araştırma grubu stresle baş } \\
\text { etme becerisi yetersiz-zaylf-düșük (stres düzeyi yüksek) öğrencilerden olușmaktadır. }\end{array}$ \\
\hline Kabul & 25.05.2016 & $\begin{array}{l}\text { Araştırma için gönüllü ögrenciler arasından bir grup seçilmiş ve bu gruba Stresle } \\
\text { Başa Çıkma Tutumları Ölçeği (SBTÖ) uygulanmıştır. Araştırmada deney grubu için }\end{array}$ \\
\hline \multicolumn{2}{|c|}{ Anahtar Sözcükler } & $\begin{array}{l}\text { Stresle Baş Etme Yaratıcı Drama Programı (SBYDP), } 9 \text { hafta, haftada bir gün ve } \\
90 \text { dakika olarak uygulanmıștır. Calıșmanın sonucunda, Stresle Baș Etme Yaratıcı }\end{array}$ \\
\hline \multicolumn{2}{|l|}{ Stres } & Drama Programının Stresle Başa Çıkma Tutumları Ölçeği'nin alt boyutlarından \\
\hline \multicolumn{2}{|c|}{ Yaratıcı drama } & aktif planlama, kaçma-soyutlama 2 ve kabul bilişsel yeniden yapılanma puanlarında \\
\hline \multicolumn{2}{|c|}{ Üniversite öğrencileri } & anlamlı farklılıklar oluşturarak etkili olduğu söylenebilir. \\
\hline
\end{tabular}

\section{Stress and Creative Drama: A Study Conducted by University Students}

\begin{tabular}{|c|c|c|}
\hline \multicolumn{2}{|c|}{ Article Info } & Abstract \\
\hline \multicolumn{2}{|c|}{ DOI: $10.21612 /$ yader.2016.004 } & The purpose of this research is to investigate the effect of "Stress-Coping Through \\
\hline \multicolumn{2}{|c|}{ Article History } & ping skills are at the lower-level. This research is a quasi-experimental study \\
\hline Received & 26.02 .2016 & $\begin{array}{l}\text { which is developed according to "single sample pre test-post test" research design. } \\
\text { The research group is selected from Aksaray University's Faculty of Education }\end{array}$ \\
\hline Revised & 14.04.2016 & students whose stress-coping skills are at lower-level and have a high-level of stress. \\
\hline Accepted & 25.05.2016 & $\begin{array}{l}\text { Scale of Stress-Coping Attitudes is carried out for building-up the experiment group } \\
\text { through volunteer students. "Stress-Coping Through Creative Drama Cirriculum }\end{array}$ \\
\hline \multicolumn{2}{|l|}{ Keywords } & $\begin{array}{l}\text { weeks. In conclusion, it is discovered that significant differences are comprised at the } \\
\text { werer }\end{array}$ \\
\hline \multicolumn{2}{|l|}{ Stress } & sub-dimensions of the scale which are active-planning, self-isolation, re-structuring \\
\hline \multicolumn{2}{|c|}{ Creative drama } & cognitive acceptance. According to this findings, it can be said SSCDC has an effect \\
\hline \multicolumn{2}{|c|}{ University student } & on the stress-coping skills level of the students. \\
\hline
\end{tabular}

* $\quad$ Bu çalışma MEB Özel Doğaç Yaratıcı Drama Liderliği Projesi’nden geliştirilmiştir.

1 Doç. Dr., Aksaray Üniversitesi, Eğitim Fakültesi, E-posta: gundogdurezzan@hotmail.com

2 Doç. Dr., Ankara Üniversitesi, Eğitim Bilimleri Fakültesi, E-posta: omeradiguzel@gmail.com 


\section{Giriş}

Stres konusunda çalışmalarıyla tanınan Hans Selye’ye göre, organizmanın fiziksel, duygusal olarak tehdit edilmesi, kendini tehdit altında hissetmesi, zorlanması sonucu ya da uyum sağlamayı gerektiren yeni bir durumun ortaya çıkması halinde stres yaşanmaktadır. Stres, farklı koşullara göre olumlu ve olumsuz etkileri ortaya çıkarabilmektedir. Selye, olumlu stresi "Eutres", olumsuz stresi ise "Distres" olarak adlandırmakta, bireyde tepki yaratan uyarıcıları "Stresör", bu stresörlere verilen tepkiyi de stres olarak ifade etmektedir (Himmetoğlu ve Kırel, 1994). Bu bağlamda uyaran rolü oynayan etkenler "stresörler", bedenin bu stresörlere tepkisi ise "stres" olarak adlandırılır.

Stres üç dönemli bir süreçte ortaya çıkar.

1. İlk dönem "Alarm Tepkisi” adını alır. Alarm safhasında birey, strese yol açan dış uyarıcılardan herhangi birini stres yapıcı bir faktör olarak algılar. Kişi bedenen veya psikolojik sınırlarının zorlandığını hisseder ve uyarımdan kaçarak ya da onunla mücadele ederek yeniden denge durumuna dönmeye çalışır. Birey bu dönemde birçok fizyolojik değişiklik yaşar ve bu uyarıyla başa çıkabileceğinden emin olmaz. Bu dönemde otonom sinir sistemi aktif duruma geçer. Salgı bezlerini uyararak kana bol miktarda adrenalin ve onun etkisi altında ortaya çıkan diğer biyokimyasal maddeleri pompalar. Salgıların etkisi altındaki beden alarm durumuna geçer ve ortaya çıkacak acil durumlarla uğraşmaya hazırlanır. Stres veren uyarıcı veya ortam devam ederse ikinci dönem ortaya çıkar.

2. İkinci basamağa "Direnç Dönemi” adı verilir. Bu dönemde, organizma yapmış olduğu alarm tepkisini ortadan kaldırır. Stresli ortama bir türlü uyum sağlar ve kandaki biyokimyasal maddeleri geri çeker. Organizma sanki normal koşullar altında işliyormuş izlenimi verir. Ne var ki gerçekte organizma yorulmaktadır ve içten içe direncini kaybetmektedir. Direniş döneminde birey fiziksel ve duygusal enerjisini harekete geçirerek strese neden olan uyarıcının olumsuz etkilerine karşı çıkmaya çalışır. Bu dönemde organizmanın alarm döneminde gösterdiği bedensel ve ruhsal belirtiler ortadan kalkar. Birey, strese neden olan uyarıyla başarılı bir şekilde baş edebilirse tükenme safhası ortaya çıkmaz.

3. Ancak uyarıcının çok şiddetli olması ve bireyin uzun süre bu uyarıcıya maruz kaldığ 1 durumlarda "Tükenme Dönemi” ortaya çıkarak yıkım ve bitkinlik yaşanır. Üçüncü basamağ1 oluşturan tükenme döneminde beden; artık stresin baskısına dayanamaz, direncini kaybeder, ilk alarm dönemindeki bazı belirtiler geri döner, hastalıklar ortaya çıkmaya başlar ve bu hastalıklardan bazıları ölümle sonuçlanabilir. Stres verici olay çok ciddi ise ve uzun sürerse organizma için tükenme aşamasına gelinir. Bazen bu dönemde yeniden alarm dönemi reaksiyonları ortaya çıkar (Baltaş ve Baltaş, 1997).

\section{Stresin Bireysel Sonuçları}

Tablo 1'de stresin bireysel sonuçları sırayla; davranışsal, psikolojik veya fizyolojik düzeyinde belirtilmiştir (Öner ve Le Compte, 1983). Stres, genel olarak bireyin doğal düzenini bozan, psikolojik bir durumdur. Bireyin üzerinde stresin, davranışsal, fizyolojik ve psikolojik bakımdan çeşitli etkileri vardır. 
Tablo 1. Stresin Bireysel Sonuçları

\begin{tabular}{|l|l|l|}
\hline Davranışsal & Psikolojik & Fizyolojik \\
\hline Sigara & Aile sorunları & Kalp hastalıkları \\
\hline Alkol & Uyku düzensizlĭgi & Baş ve sırt ağrısı \\
\hline Kaza yapma & Depresyon & Kanser \\
\hline Şiddet & Psikolojik rahatsızlıklar & \\
\hline İsteksizlik & Tükenme belirtisi & \\
\hline
\end{tabular}

(Kaynak: Öner ve Le Compte, 1983, s. 1)

\section{Stresin Davranışsal Sonuçları}

Stresten kaçınmak için bireylerin en çok başvurduğu davranış kalıpları arasında sigara, alkol, çeşitli uyarıcılar, uyuşturucu madde kullanımı, aşırı yemek yeme, uyku düzensizliği gibi zararlı alışkanlıklar yer almaktadır. Alkol alma eğilimi en çok görülen davranışsal sonuçtur. Günlük sorunlardan kurtulmak için başvurulan alkolün dozajı artmakta ve zamanla alışkanlık şeklini almaktadır. Aynı durum sigara, uyuşturucu ve aşırı yemek için de söz konusudur. Stresin bir diğer etkisi de kişilerin dikkatini, uyanıklığını etkileyerek kazaya neden olması veya saldırganlık duygusu yaratmasıdır (Artan, 1986).

\section{Stresin Psikolojik Sonuçları}

Stres sonucunda bireylerde ortaya çıkan psikolojik rahatsılılıların en belirginleri; endişe, kayg1 (anksiyete), depresyon, uykusuzluk, psikolojik yorgunluk ve tükenme şeklinde kendini göstermektedir. Mocan, Allen, Baltaş, ve Timur bedenin bazı hastalıklarda olduğu gibi stresli durumlarda da bazı tepkiler verdiğini söylemektedir. Bu tepkiler (Rosch, 1986; Baltaş ve Baltaş, 1999; Mocan, 1987); tansiyon yükselmesi, sindirim bozukluğu, terleme, nefes darlığ1, baş ağrıs1, yorgunluk, alerji ve mide bulantısidır.

\section{Stresin Fizyolojik Sonuçları}

Günümüzde birçok hastalığın stresle olan ilişsisindeki açıklık giderek artmaktadır. Aşağıda sayılan hastalıkların oluşmasında diğer faktörler yanında stresin de etkili olduğu bilinmektedir (Kırel, 1994, s.48).

A. Dolaşım Sistemi, Kalp ve Damar Hastalıkları: Çarpıntı, kalp atışlarında düzensizlikler ve artışlar, göğüs ağrısı, miyokart enfarktüsü, hiper tansiyon.

B. Solunum Sistemi Hastalıkları: Aşırı soluk alıp verme, bronşiyal astım.

C. Sindirim Sistemi Hastalıkları: İştahın kesilmesi, aşııı yemek yeme, hazımsızlık gastrit ve ülser gibi hastalıklar.

D. Üreme Sistemi Hastalıkları: Cinsellikle ilgili rahatsılıklar.

E. İç Salgı Bezi Hastalıkları: Hipertroid, şeker hastalığı.

F. Deri Hastalıkları: Kurdeşen, egzama, sedef hastalıkları, saç dökülmesi ve kı1 dökülmesi. 
G. Hareket Sistemi Hastalıkları: Kireçlenme, kas gerilemesine bağlı hastalıklar, migren kronik baş ağrıları.

Yukarıda da görüldüğü gibi stresin bireyler üzerinde farklı sonuçları olmaktadır. Bu sonuçlar genellikle bireyi hem fiziksel hem de psikolojik sağliksızlığa doğru iten, bireyin yaşam kalitesini düşüren ve kişilerarası ilişkilerini bozabilen bir noktaya da taşıyabilmektedir. Stres, günümüz yaşam biçimi içeresinde yer alan ve bireylerin bununla baş etmede farklı yollar aramalarına neden olan kaçınılmaz bir olgudur. Stresle baş etmek için farklı yöntemler araştırılmaktadır.

Yaratıcı drama, birçok alanda kullanılabilen bir yöntem olarak dikkat çekmektedir. Türkçe, tarih, coğrafya, matematik, psikoloji gibi temel derslerden ekonomi, politika, endüstri, insan ilişkileri gibi alanlarda yaratıcı drama çalışmalarına rastlanmaktadır.

Yaratıcı drama ortamında katılımcılar yaratarak, geliştirerek ve yansıtarak kendilerini, arkadaşlarını, ailelerini ve içinde yaşadıkları gerçek dünyaya ait birçok yeni yaşantının farkına varırlar. Çeşitli sosyal olayları inceleme olanağı bularak, insanların farklı koşullarda ne şekilde davrandıkları ile ilgili düşünmeye başlarlar. Farklı görüşler ortaya koyarlar, diğer insanların görüşlerini tahlil edebilirler. Bu da katılımcıları düşünce ayrılığı, tartışma ve çözüme götürür (Fulford ve ark., 2001).

Yaratıcı drama eğitim programları aynı zamanda sosyal beceri eğitimini de amaçlamaktadır. Sosyal beceri eğitiminde kullanılan bazı teknikler arasında model alma, liderlik, davranışların prova edilmesi-rol oynama, geri bildirim verme, sosyal alg1 ve ev ödevleri vardır. Yaratıcı dramada ise genellikle bu teknikler yer almakta böylece eğitimin bilişsel, duyuşsal ve davranışsal boyutlarını da içermektedir (Akfirat, 2006). Bu içeriğin örgün eğitim içerisinde yer alan aynı zamanda çağdaş eğitim anlayışının unsurlarından biri olan psikolojik danışma ve rehberlik hizmetleri ile yer yer örtüştüğü de görülebilir. Rehberliğin çalışma alanlarından biri de kişisel-sosyal rehberlik hizmetleridir. Kişiselsosyal rehberlik hizmetleri arasında özgüven, öz sayg1, benlik algısı, sosyalleşme, stres, kaygı, öfke vb. başa çıkma, çatışma çözme becerileri, atılganlık becerileri gibi konular yer almaktadır. San (2002)'a göre öğrenme ve sosyalleşme sürecine etkisi dışında yaratıcı drama, kimine göre benlik saygısını geliştirir, kimine göre grup üyesi olmanın getirdiği gizil gücü vurgular, kimilerine göre de iletişim ve problem çözme becerilerini geliştirir. Bu becerilerin öğrenci/bireylere öğretilmesinde yani bu konuların yer aldığı kişisel-sosyal rehberlik etkinliklerinin planlanmasında yaratıcı drama alanından yararlanılabilir.

\section{Stresle Baş Etme ve Yaratıcı Drama}

Yaratıcı drama etkinliklerinin ortak hedefinin sosyal gelişme olduğu söylenebilir. Yaratıcı drama ilk önce insanın kendini anlamasını ve kabul etmesini daha sonra da başkalarını anlama, kabul etme ve onlarla paylaşımlarını geliştirerek bireyin sosyal gelişimi sağlar. Yaratıcı drama özellikle tehdit edici olmayan bir ortamda, katılımcılara duygusal rahatlama sağlayarak sosyal becerilerini geliştirme olanağı verir (Akfirat, 2006).

Yaratıcı drama çalışmalarında katılımcılar yeni ürünler ortaya koyabilir, başkalarıyla paylaşma, birlikte çalışma ve kendini keşfetme olanakları edinebilir, her türlü (yazılı, sözel, bedensel) ifade becerisini geliştirebilir, doğaçlamalar yapabilir, şiir, öykü vd. edebi türleri okuyabilir, bu türlerde örnekler oluşturabilir, resimlerden yararlanabilir, resim yapabilir, sanata daha fazla ilgi duyabilirler (Adıgüzel, 1993; Akfirat, 2002; Barnes, 1998; Davies, 1984; Gönen, 2001; Johanian, 1997; McCaslin, 1990; Ömeroğlu, 1992, Akt: Akfirat, 2006). 
Araştırmalar duyuşsal ve bilişsel ögelerin düşünme ve problem çözmeyle birlikte kullanıldığında daha etkili olduğunu ortaya koymuştur. Yaratıcı drama çalışmaları, motivasyon, çatışmaları çözme, problemler karşısında uygun çözüm yoluna karar verme gibi kendine özgü değeri olan öğrenme yaşantıları sunar. Bu süreç içinde çocuklar, empati kurmayı öğrenerek toplumsal yaşama katılama becerilerini geliştirebilirler (Peter, 1994).

John Somers, yaratıcı dramanın dolaylı olarak terapotik etkisinden söz ederken "bazıları tüm drama deneyimlerinin terapötik etkisi olduğunu iddia etmektedir. En azından 'iyi bir şey yapma' beklentileri vardır. Belirli drama etkinlikleri potansiyel olarak karmaşık psikolojik ve duygusal değişimlere ulaşmayı hedeflemektedir (Somers, 2008, s.115)" görüşündedir. Araştırmalar, uygulamalı drama ve tiyatroya dahil olmanın, tutum ve davranış geliştirmenin etkili yollarından biri olduğunu göstermektedir (Somers, 2008, s.116). Yine Somers (2008, s.119) drama ve iyi oluş üzerinde dururken J. Catterall'in araştırmalarının sonucunda davranış değiştirmede; dramanın sosyal ilişkileri, karmaşık sorunları ve duyguları anlamaya yardımcı olduğunu da vurgulamaktadır.

Yaratıcı dramanın sahip olduğu özellikler, amaçlar ve uygulanma biçimleri ile psikolojik danışma ve rehberlik hizmetleri arasında rahatlıkla bir ilişki kurulabilir. Bu yönüyle yaratıcı dramanın bireye; kendini tanıma, hayatı, olayları ve sorunları gerçekçi bir biçimde algılama, kendi sorunlarını çözebilme yönünde destek olması nedeniyle, aynı zamanda bireyin kişisel ve sosyal gelişimini sağlayan bir grup rehberliği yöntemi olabileceği söylenebilir.

$\mathrm{Bu}$ çalışma, yaratıcı drama yöntemi kullanılarak üniversite öğrencilerinin yaşadıkları stresle baş edebilme becerilerini geliştirmeye yönelik olarak yapılandırılmıştır. Çalışma, üniversite öğrencilerinin stresle baş etmesinde denenmiş bir programın ortaya çıkmasında az sayıdaki programlardan biri olması nedeniyle bir özgünlük taşımaktadır. Ayrıca uygulanan program, öğrenci merkezli ve öğrencilerin yaşantılarına dayalı bir içerikle hazırlanması nedeniyle bir öneme sahiptir. Yaratıcı drama alanı doğrudan bir iyileştirme amacı taşımadığı için uygulama sürecinde de hazırlanan program, temel drama yaklaşımlarını kapsar nitelikte tasarlanmıştır. Bu nedenle uygulanan atölyeler doğrudan bir iyileştirme amacına göre hazırlanmamış, konu daha çok dolaylı yollardan irdelenmiştir.

Böylece program, öğrencilerin yaratıcılıklarını da işin içine katmalarını sağlayacak şekilde planlanmış ve yaratıcı drama yöntemiyle etkili bir psiko-eğitim sürecine dönüştürülebilme özelliğine sahip olmuştur. Yaratıcı drama, süreç odaklı olduğu ve üründen daha çok süreci göz önünde bulundurduğu için uygulama etkinlikleri öğrencilerin, bağımsız düşünebilmesinde, farkındalıklarının arttırılmasında, sağ lık 1 ilişkiler kurabilmelerinde, hoşgörülü ve yaratıcı bireyler olarak yetişmelerinde ve sosyal bir kimlik geliştirmelerinde önemli bir işlevi olabilmesine dönük olmuştur.

\section{Yöntem}

$\mathrm{Bu}$ çalışma yaratıcı drama etkinliklerinin üniversite öğrencilerinin stresle baş etme becerilerine etkisini araştırmak amacıyla gerçekleştirilen zayıf deneysel desenlerden, "tek grup öntest-sontest desen" deneme modeline göre geliştirilmiş yarı deneysel bir çalışmadır.

\section{Çalışma Grubu}

Çalışma grubunu 2012-2013 eğitim-öğretim yılında Aksaray ili, Aksaray Üniversitesi Eğitim Fakültesi'nde öğrenim gören öğrenciler oluşturmaktadır. Proje 17-25 yaş arası üniversite eğitimine devam eden stres düzeyleri yüksek ve grup çalışmasına katılmaya gönüllü bireylerle 
gerçekleştirilmiştir. Deneysel uygulamalarda gönüllülük ilkesinin önemi göz önüne alınarak programa öğrenci alınmasına dikkat edilmiştir. Her gruba 12 ile 16 arasında kişinin atanmasının uygun olabileceğinin nedeni olarak Acar'ın (1995), grupla psikolojik danışmanın gönüllü üyeler ile 8-12 kişilik gruplarla çalışabilir ve Adıgüzel'in (1994), sağlıklı sonuçlar alınabilecek bir drama grubunun sayısı, yaş gruplarına göre değişmekle birlikte okulöncesi ve ilkokul birinci basamak çocukları dışında, genelde 12-15 kişilik grupların ideal olarak kabul edilebileceğine ilişkin görüşleri dikkate alınmıştır. Bu doğrultuda gönüllü öğrencilerden oluşan grubun 10’u kız, 8'i erkek olmak üzere heterojen bir grup olması sağlanarak toplam 18 kişidir.

\section{Veri Toplama Araçları}

$\mathrm{Bu}$ çalı̧̧mada stres düzeyi yüksek öğrencilerin belirlenmesi için "Stresle Başa Çıkma Tutumları Ölçeği”, “Öğrenci Görüşme ve Etkinlik Değerlendirme Formu” ve öğrencilerin demografik bilgilerinin belirlenebilmesi için "Kişisel Bilgi Formu” kullanılmıştır.

Çalışmada kullanılan "Öğrenci Görüşme ve Etkinlik Değerlendirme Formu” açık uçlu 5 sorudan oluşmuştur. Sorular şu şekildedir: Yaşamınızdaki stres ile baş etme yollarınız neler? Bu projeye başlamadan önce stres ile nasıl baş ediyordunuz? Bu projeye katıldıktan sonra stresle nasıl baş ediyorsunuz? Projeye katılmadan önceki beklentilerinize ulaşabildiniz mi? Evet () Hayır () Evet veya Hayır ise beklentileriniz nelerdi? Projeye katılma konusunda çevrenizdeki tanıdıklarınıza neler önerirsiniz?

Çalışmada üniversite öğrencilerinin stresle başaçıkma stillerini belirlemek için "Stresle Başa Çıkma Tutumları Ölçeği” kullanılmıştır. Ölçeğin esas formu Özbay (1993), tarafından Amerika Birleşik Devletleri’nde, üniversitede öğrenim gören yabanc1 uyruklu öğrencilere yönelik geliştirilmiş olan “Stresle Başaçıkma Yolları” ölçeğidir. Envanterin Türkçe uyarlaması, Özbay ve Şahin (1997), tarafından yapılmıştır. Geliştirilen bu envanterin amacı, farklı stres durumlarında bireylerin başa çıkma stillerini ölçmeye yöneliktir. Türkçe uyarlama çalışmasında faktör analizi sonucunda başa çıkma ölçeği 43 ifade, 6 faktör altında toplanmıştır. Ölçek, 5'li likert tipi derecelendirmeyle düzenlenmiş ve araştırmaya katılan öğrencilerden her maddeyi okuyup "hiçbir zaman", "ara sıra", "bazen", "sık sık", "her zaman” seçeneklerinden birinin işaretlemeleri istenmiştir. Yine öğrencilerden ölçeği yanıtlarken her maddede kendine en uygun ifadeyi tercih edip işaretlemeleri istenmiştir. Faktör analizi tekniği ile belirlenen altı faktör; aktif planlama, dış yardım arama, dine sığınma, kaçma-soyutlama (duygusal-eylemsel), kaçma soyutlanma (biyokimyasal) ve kabul-bilişsel yeniden yapılanma olarak adlandırılmıştır. Yapı faktör analizinin yanında, ölçüt geçerliği de benzer ölçek yardımı ile testin geçerliğine ilişkin bulgular elde edilmiştir. Şahin ve Durak (1995) tarafından Türkçe'ye uyarlanan Stresle Başa Çıkma Tarzları Ölçeği ölçüt olarak alınmıştır. S.B.T.Ö ile S.B.T.E arasında genel olarak $.54(\mathrm{p}<.001)$ düzeyinde bir ilişski bulunmuştur. Testin güvenirlik hesapları Cronbah Alfa iç tutarlılık yöntemiyle gerçekleştirilmiştir. Testin genel güvenirlik katsayısı .81 olarak bulunmuştur. Özbay ve Şahin (1997), bu altı faktörü şöyle tanımlamıştır:

1. Aktif Planlama: Daha çok aktif olarak bir şeyler yapma, doğrudan işleme başlama, aktif çabaları artırma, eylem planları oluşturma, şu an üzerinde odaklaşma ve problem çözme sistematiği içerisinde olmayı içeren rasyonel adımlar ve yöntemleri kapsayan 10 maddeden $(2,3,5,7,16,19,25,32,35,37)$ oluşmaktadır.

2. Dış Yardım Arama: Sosyal desteğe başvurma iki açıdan söz konusu olabilmektedir. Bunlar somut çözüme yönelik (enstürmental) dış yardım talebi ve duygusal dış yardım arama eğilimidir. Bu alt ölçek yardım arama tutumlarının duygusal, bilişsel ve fiziksel boyutta ölçümünü amaçlayan 9 maddeden $(1,8,9,10,11,14,29,33,38)$ oluşmaktadır. 
3. Dine Sı̆̆ınma (Dine Yönelme): Bu faktör altında toplanan maddeler daha çok bir ilahi güce sığınmayı, dua etmeyi ve inançlardan güç almayı vurgulamaktadır. Bu faktör 6 madde $(12,13,17,20,21,31)$ ile temsil edilmektedir.

4. Kaçma-Soyutlama (Duygusal-Eylemsel): Kaçma-Soyutlama iki boyutlu olarak faktöriyel yapıda yer almıştır. Bu maddeler kişinin stresle başa çıkma tutumlarını pasif anlamda durumdan kendisini soyutlama biçiminde ele almaktadır ve 7 maddeden (4, $6,15,22,30,39,41)$ oluşmaktadır.

5. Kaçma-Soyutlanma (Biyokimyasal): Bu boyut duygusal-eylemsel kaçma ve soyutlamadan farklı ve pasif bir başa çıkma stratejisi olarak metabolizmada fizyolojik değişiklik yapma eğilimi şeklinde değerlendirilebilir. Sigara içme, alkol alma, ilaç kullanma ve uyuşturucuya yönelme gibi başaçıkma yollarıdır. Bu faktör 4 madde (18, $23,24,28)$ ile temsil edilmektedir.

6. Kabul-Bilişsel Yeniden Yapılanma: Problemin kabul edilip kendince bilişsel olarak yeni çözüm yollarının aranmasıdır. Bu alt ölçek 7 maddeden $(26,27,34$, 36, 40, 42, 43) oluşmaktadır ve başa çıkmada kişisel olarak durumun değiştirilmesine yönelik bir işlemden çok kişinin bakış açısını vurgulamaktadır.

\section{Verilerin Toplanması}

Verilerin toplanmasında ilk olarak öğrencilere Stresle Başa Çıkma Yaratıcı Drama Programı'na (SBYDP) başlamadan önce ön test amaçlı ölçek ve formlar uygulanmış, programa katılmaya gönüllü ve stres puanları yüksek bireyler seçilmiştir. Program bittikten sonra aynı ölçek ve formlar programa katılan katılımcılara tekrar uygulanmıştır.

\section{Uygulama}

Deney grubuyla Stresle Başa Çıkma Yaratıcı Drama Programı (SBYDP) ön testlerin uygulanmasından sonra çalışma başlamıştır. Araştırma iki aşamada gerçekleştirilmiştir. İlk aşamada uygulama öncesi hazırlıklar yapılmış ve gerekli izinler alınmış iken ikinci aşamada uygulama çalışmaları gerçekleştirilmiştir. Her bir oturum 90 dakika ve toplam 9 oturum olarak planlanmıştır. Deney grubu ile SBYDP'nın uygulaması öğrencilerle birlikte belirlenen gün ve saatte başlanmış ve 9 hafta aynı şekilde devam etmiştir. Araştırma Aksaray Üniversitesi Eğitim Fakültesi "Drama Atölyesi”nde gerçekleştirilmiştir. SBYDP'nin oturumları aşağıdaki şekilde planlanmıştır;

1. Oturum: Tanışma

2. Oturum: İşbirliği ve Güven

3. Oturum: Stres hakkında bilgi sahibi olma

4. Oturum: Stresin fiziksel, psikolojik ve davranışsal sonuçları hakkında bilgi sahibi olma

5. Oturum: Gevşeme egzersizinin aşamaları hakkında bilgi sahibi olma

6. Oturum: "Hayal kurma" hakkında bilgi sahibi olma

7. Oturum: Stres aşısı tekniği hakkında bilgi sahibi olma

8. Oturum: "Kişisel kontrol" stratejisi hakkında bilgi sahibi olma

9. Oturum: Sonlandırma- Değerlendirme 


\section{Verilerin Analizi}

Stresle Başa Çıkma Tutumları Ölçeği’nden (SBTÖ) elde edilen nicel veriler SPSS 17 bilgisayar paket programında çözümlenmiştir. Deney grubunun katılımcı sayısının 30 kişiden az olması nedeniyle SBTÖ'den elde edilen veriler için nonparametrik teknikler kullanılmış ve deney grubu iki farklı ölçümün (ön-son test) ayrı ayrı etkileri ilişkili iki ölçüm setine uygulanan Wilcoxon İşaretli Sıralar Testi ile test edilmiştir. Öğrencilerin görüş ve düşüncelerini belirlemek amaciyla uygulanan “Öğrenci Görüşme ve Etkinlik Değerlendirme Formu'ndan” elde edilen nitel veriler ise içerik analizi yöntemi ile çözümlenmiştir.

\section{Bulgular ve Yorum}

Stresle Başa Çıkma Yaratıcı Drama Programı'nın (SBYDP) üniversite öğrencilerinin stresle baş etme becerilerine etkisinin incelenmesi amacıyla planlanan bu çalışmanın verileri çözümlenerek tablolar halinde aşağıda verilmiştir.

Araştırma grubu oluşturulmadan önce ön ölçümlerin yapıldı ğı grubun demografik özellikleri Tablo 2'de gösterilmiştir.

Tablo 2. Ön Ölçümlerin Yapıldığı Grubun Demografik Özellikleri

\begin{tabular}{|c|c|c|}
\hline Araştırma Grubu & n & $\%$ \\
\hline \multicolumn{3}{|l|}{ Yaş } \\
\hline $18-24$ & 63 & 95.5 \\
\hline 24 yaş üzeri & 3 & 4.5 \\
\hline \multicolumn{3}{|l|}{ Cinsiyet } \\
\hline Kız & 48 & 72.7 \\
\hline Erkek & 18 & 27.3 \\
\hline \multicolumn{3}{|l|}{ Barınma Şekli } \\
\hline $\mathbf{E v}$ & 27 & 40.9 \\
\hline Yurt & 39 & 59.1 \\
\hline \multicolumn{3}{|l|}{ Algıladıkları Ekonomik } \\
\hline \multirow[t]{4}{*}{ Durum } & 14 & 21.2 \\
\hline & 49 & 74.2 \\
\hline & 3 & 4.5 \\
\hline & & \\
\hline TOPLAM & 66 & 100 \\
\hline
\end{tabular}

Stresle Baş Etme Tutumları Ölçeği’nin (SBTÖ) uygulanmasının ve çalışmaya gönüllü olanlar arasından seçilerek oluşturulan araştırma grubunun yani deney grubunun cinsiyete gore dağılımı Tablo 3'te gösterilmiştir. 
Tablo 3. Deney Grubunun Cinsiyete Göre Dă̆ılımı

\begin{tabular}{rll}
\hline \multicolumn{1}{l}{ Cinsiyet } & Kız & Erkek \\
\hline $\mathrm{n}$ & 10 & 8 \\
$\%$ & 55.5 & 44.5 \\
TOPLAM & 18 & 100 \\
\hline
\end{tabular}

Tablo 3'te araştırmayı oluşturan deney grubundaki toplam kız ve erkek katılımcı sayılarının dengede olduğu görülmektedir.

Deney grubunun Stresle BaşaçıkmaTutumları Ölçeği (SBTÖ), ön-son ölçüm puanlarına ilişkin n değeri, aritmetik ortalama ve standart sapmaları Tablo 4'de verilmiştir.

Tablo 4. Deney Grubunun Stresle Başa Çıkma Tutumları Ölçeği (SBTÖ) Alt Ölçekler Ön-Son Test Puanlarının $N$ değeri, Aritmetik Ortalama ve Standart Sapma Değerleri

\begin{tabular}{|c|c|c|c|}
\hline $\begin{array}{l}\text { Deney } \\
\text { SBTÖ-A }\end{array}$ & $\mathbf{N}$ & $\bar{X}$ & SS \\
\hline \multicolumn{4}{|c|}{ Aktif Planlama } \\
\hline Ön test & 18 & 23.44 & 5.98 \\
\hline Son test & 18 & 26.67 & 5.90 \\
\hline \multicolumn{4}{|c|}{ Dış Yardım Arama } \\
\hline Ön test & 18 & 21.66 & 5.40 \\
\hline Son test & 18 & 22.67 & 5.75 \\
\hline \multicolumn{4}{|c|}{ Dine Sı̆̆ınma } \\
\hline Ön test & 18 & 13.50 & 5.90 \\
\hline Son test & 18 & 13.50 & 5.44 \\
\hline \multicolumn{4}{|c|}{ KaçmaSoyutlama1 } \\
\hline Ön test & 18 & 13.83 & 4.20 \\
\hline Son test & 18 & 15.11 & 3.70 \\
\hline \multicolumn{4}{|c|}{ KaçmaSoyutlama2 } \\
\hline Ön test & 18 & 7.61 & 1.29 \\
\hline Son test & 18 & 5.89 & 1.64 \\
\hline \multicolumn{4}{|c|}{ K. Bilişsel Yapılama } \\
\hline Ön test & 18 & 13.67 & 3.54 \\
\hline Son test & 18 & 16.50 & 4.19 \\
\hline
\end{tabular}

Tablo 4'te deney grubunun ön test puanlarının $\mathrm{n}$ değeri, aritmetik ortalamaları ve standart sapmaları görülmektedir. 


\section{Deney Grubunun Stresle Başa çıkma Tutumları Ölçeği (SBTÖ) Alt Ölçeklerine İlişkin Ön-Son Ölçümleri Bulguları}

\section{SBTÖ-Aktif Planlama}

“Stresle Başa Çıkma Yaratıcı Drama Programı'na (SBYDP) katılan deney grubundaki üniversite öğrencilerinin SBTÖ-Aktif Planlama alt ölçeği ön test-son test puanları arasında son test lehine anlamlı bir fark vardır." denencesini sınamak için deney grubundaki üniversite öğrencilerinin aktif planlama alt ölçeği ön test-son test puanları arasında istatistiksel olarak anlamlı bir farkın olup olmadığı ilişkili iki ölçüm setine uygulanan Wilcoxon İşaretli Sıralar Testi ile araştırılmış ve elde edilen sonuçlara ilişkin bulgular Tablo 5' de gösterilmiştir.

Tablo 5. Deney Grubundaki Üniversite Öğrencilerinin Stresle Başaçıkma Tutumları Ölçeğinin Aktif Planlama Alt Ölçeği Ön test-Son test Puanlarına İlişkin Wilcoxon İşaretli Stralar Testi Sonuçları

\begin{tabular}{lllllll}
\hline Gruplar & Sira İşareti & $\mathrm{n}$ & Sira ortalaması & Sira toplamı & $\mathrm{z}$ & $\mathrm{p}$ \\
\hline Deney & Negatif Sıra (-) & 4 & 7.00 & 28.00 & -2.31 & .021 \\
& Pozitif Sira (+) & 13 & 9.62 & 125.00 & & \\
& Nötr (=) & 1 & & & & \\
\hline
\end{tabular}

* Negatif sıralar temeline dayalı

Tablo 5’te verilen Wilcoxon İşaretli Sıralar Testi sonuçlarına göre deney grubundaki üniversite öğrencilerinin aktif planlama düzeylerinin (puanlarının), Stresle Başa Çıkma Yaratıcı Drama Programına (SBYDP) katılmadan önceki ve programa katıldıktan sonraki puanları arasında anlamlı bir farklılık olduğu görülmektedir $(\mathrm{z}=-2.31, \mathrm{p}<0.05)$. Fark puanlarının sira toplamı dikkate alındığında, gözlenen bu farkın son test puanı lehine olduğu görülmektedir. Bu sonuçlar denenceyi desteklemekte ve SBYDP'nin, üniversite öğrencilerinin SBTÖ-AktifPlanlama alt ölçeği düzeylerinin (puanlarının) artmasında etkili olduğunu göstermektedir denilebilir.

\section{SBTÖ-Dış Yardım Arama}

“Stresle Başa Çıkma Yaratıcı Drama Programı'na katılan geney grubundaki üniversite öğrencilerinin SBTÖ-D1ş Yardım Arama alt ölçeği ön test-son test puanları arasında anlamlı bir fark vardır" denencesini sınamak için deney grubundaki üniversite öğrencilerinin dış yardım arama alt ölçeği ön test-son test puanları arasında istatistiksel olarak anlamlı bir farkın olup olmadığı ilişkili iki ölçüm setine uygulanan Wilcoxon İşaretli Sıralar Testi ile araştırılmış ve elde edilen sonuçlara ilişkin bulgular Tablo 6'da gösterilmiştir. 
Tablo 6. Deney ve Kontrol Grubundaki Üniversite Öğrencilerinin Stresle Başaçıkma Tutumları Ölçeğinin Dış Yardım Arama Alt Ölçeği Ön test-Son test Puanlarına İlişkin Wilcoxon İşaretli Siralar Testi Sonuçları

\begin{tabular}{lllllll}
\hline Gruplar & Sıra İşareti & $\mathrm{n}$ & Sira ortalaması & Sıra toplamı & $\mathrm{z}$ & $\mathrm{p}$ \\
\hline Deney & Negatif Sıra (-) & 4 & 7.88 & 63.00 & -.641 & .522 \\
& Pozitif Sıra (+) & 13 & 10.00 & 90.00 & & \\
& Nötr (=) & 1 & & & & \\
\hline
\end{tabular}

* Negatif siralar temeline dayalı

Tablo 6'da verilen Wilcoxon İşaretli Sıralar Testi sonuçlarına göre deney grubundaki üniversite öğrencilerinin dış yardım arama düzeylerinin (puanlarının), Stresle Başaçıkma Yaratıcı Drama Programına'na (SBYDP) katılmadan önceki ve programa katıldıktan sonraki puanları arasında anlamlı bir farklılık olmadığ görülmektedir ( $\mathrm{z}=-.641, \mathrm{p}>0.05)$. Bu sonuçlar denenceyi desteklememekte ve SBYDP, üniversite öğrencilerinin SBTÖ-Dış Yardım Arama alt ölçeği düzeylerinde (puanlarında) herhangi bir farklılığa yol açmamıştır denilebilir.

\section{SBTÖ-Dine Sığınma}

“Stresle Başa Çıkma Yaratıcı Drama Programı'na katılan deney grubundaki üniversite öğrencilerinin SBTÖ-Dine Sığınma alt ölçeği ön test-son test puanları arasında anlamlı bir fark vardır." denencesini sınamak için deney grubundaki üniversite öğrencilerinin dine sığınma alt ölçeği ön test-son test puanları arasında istatistiksel olarak anlamlı bir farkın olup olmadığı ilişkili iki ölçüm setine uygulanan Wilcoxon İşaretli Sıralar Testi ile araştırılmış ve elde edilen sonuçlara ilişkin bulgular Tablo 7'de gösterilmiştir.

Tablo 7. Deney Grubundaki Üniversite Öğrencilerinin Stresle Başaçıkma Tutumları Ölçeğinin Dine Sı̆̆ııma Alt Ölçeği Ön test-Son test Puanlarına İlişkin Wilcoxon İşaretli Siralar Testi Sonuçları

\begin{tabular}{llllllc}
\hline Gruplar & Sıra İşareti & $\mathrm{n}$ & Sıra ortalaması & Sıra toplamı & $\mathrm{z}$ & $\mathrm{p}$ \\
\hline \multirow{2}{*}{ Deney } & Negatif Sıra (-) & 7 & 7.57 & 53.00 & -.032 & .975 \\
& Pozitif Sıra (+) & 7 & 7.49 & 52.00 & & \\
& Nötr (=) & 4 & & & & \\
\hline
\end{tabular}

* Negatif siralar temeline dayalı

Tablo 7'de verilen Wilcoxon İşaretli Sıralar Testi sonuçlarına göre deney grubundaki üniversite öğrencilerinin dine sığınma düzeylerinin (puanlarının), Stresle Başa Çıkma Yaratıcı Drama Programı'na (SBYDP) katılmadan önceki ve programa katıldıktan sonraki puanları arasında anlamlı bir farklılık olmadığı görülmektedir ( $\mathrm{z}=.975, \mathrm{p}>0.05)$. Bu sonuçlar denenceyi desteklememekte ve SBYDP'nin, üniversite öğrencilerinin SBTÖ-Dine Sığınma alt ölçeği düzeylerinde (puanlarında) etkili olmadığını göstermektedir denilebilir. SBYDP’ye katılan üniversite öğrencilerinin stresle baş etmede dine sığınma davranışı göstermelerinde herhangi bir farklılığa yol açmamıştır. 


\section{SBTÖ-Kaçma-soyutlama 1}

“Stresle Başa Çıkma Yaratıcı Drama Programı’na katılan deney grubundaki üniversite öğrencilerinin SBTÖ-Kaçma-Soyutlama 1 alt ölçeği ön test-son test puanları arasında anlamlı bir fark vardır." denencesini sınamak için deney grubundaki üniversite öğrencilerinin kaçma-soyutlama 1 alt ölçeği ön test-son test puanları arasında istatistiksel olarak anlamlı bir farkın olup olmadığı ilişkili iki ölçüm setine uygulanan Wilcoxon İşaretli Sıralar Testi ile araştırılmış ve elde edilen sonuçlara ilişkin bulgular Tablo 8'de gösterilmiştir.

Tablo 8. Deney Grubundaki Üniversite Öğrencilerinin Stresle Başaçıkma Tutumları Ölçeğinin Kaçma-Soyutlama 1 Alt Ölçeği Ön test-Son test Puanlarına İlişkin Wilcoxon İşaretli Stralar Testi Sonuçlart

\begin{tabular}{lllllll}
\hline Gruplar & Sıra İşareti & $\mathrm{n}$ & Sıra ortalaması & Sıra toplamı & $\mathrm{z}$ & $\mathrm{p}$ \\
\hline Deney & Negatif Sıra (-) & 6 & 7.17 & 43.00 & -.970 & .332 \\
& Pozitif Sıra (+) & 9 & 8.56 & 77.00 & & \\
& Nötr (=) & 3 & & & & \\
\hline
\end{tabular}

* Negatif siralar temeline dayalı

Tablo 8'de verilen Wilcoxon İşaretli Sıralar Testi sonuçlarına göre deney grubundaki üniversite öğrencilerinin kaçma-soyutlama 1 (duygusal-eylemsel) düzeylerinin (puanlarının), Stresle Başa çıkma Yaratıcı Drama Programına'na (SBYDP) katılmadan önceki ve programa katıldıktan sonraki puanları arasında anlamlı bir farklılık olmadığı görülmektedir $(z=-.970, p>0.05)$. Bu sonuçlar denenceyi desteklememekte ve SBYDP'nin, üniversite öğrencilerinin SBTÖ-kaçma-soyutlama 1 alt ölçeği düzeylerinde (puanlarında) bir farklılığa yol açmadığını göstermektedir denilebilir.

\section{SBTÖ-Kaçma-soyutlama 2}

“Stresle Başaçıkma Yaratıcı Drama Programı’na katılan deney grubundaki üniversite öğrencilerinin kontrol grubundaki üniversite öğrencilerine göre SBTÖ-Kaçma-Soyutlama 2 alt ölçeği ön test-son test puanları arasında son test lehine anlamlı bir fark vardır." denencesini sınamak için deney grubundaki üniversite öğrencilerinin kaçma-soyutlama 2 alt ölçeği ön test-son test puanları arasında istatistiksel olarak anlamlı bir farkın olup olmadığ 1 ilişkili iki ölçüm setine uygulanan Wilcoxon İşaretli Sıralar Testi ile araştırılmış ve elde edilen sonuçlara ilişkin bulgular Tablo 9'da gösterilmiştir.

Tablo 9. Deney Grubundaki Üniversite Öğrencilerinin Stresle Başaçıkma Tutumları Ölçeğinin Kaçma-Soyutlama 2 Alt Ölçeği Ön test-Son test Puanlarına İlişkin Wilcoxon İşaretli Stralar Testi Sonuçları

\begin{tabular}{llcllll}
\hline Gruplar & Sıra İşareti & $\mathrm{n}$ & Sira ortalaması & Sira toplamı & $\mathrm{z}$ & $\mathrm{p}$ \\
\hline Deney & Negatif Sıra (-) & 13 & 11.42 & 148.50 & -2.776 & .005 \\
& Pozitif Sıra (+) & 5 & 4.50 & 22.50 & & \\
& Nötr (=) & 0 & & & & \\
\hline
\end{tabular}

* Negatif sıralar temeline dayalı 
Tablo 9' da verilen Wilcoxon İşaretli Sıralar Testi sonuçlarına göre deney grubundaki üniversite öğrencilerinin kaçma-soyutlama 2 (Biyokimyasal) düzeylerinin (puanlarının), Stresle Başa Çıkma Yaratıcı Drama Programı'na (SBYDP) katılmadan önceki ve programa katıldıktan sonraki puanları arasında anlamlı bir farklılık olduğu görülmektedir $(\mathrm{z}=-2.776, \mathrm{p}<0.05)$. Fark puanlarının sıra toplamı dikkate alındığında, gözlenen bu farkın son test puanı lehine olduğu görülmektedir. Bu sonuçlar denenceyi desteklemekte ve SBYDP'nin, üniversite öğrencilerinin SBTÖ-Kaçma-Soyutlama 2 alt ölçeği düzeylerinin (puanlarının) azalmasında etkili olduğunu göstermektedir, denilebilir.

\section{SBTÖ-Kabul Bilişsel Yeniden Yapılanma}

“Stresle Başaçıkma Yaratıcı Drama Programı’na katılan deney grubundaki üniversite öğrencilerinin SBTÖ-Kabul Bilişsel Yeniden Yapılanma alt ölçeği ön-test son-test puanları arasında son test lehine anlamlı bir fark vardır." denencesini sınamak için deney grubundaki üniversite öğrencilerinin kabul bilişsel yeniden yapılanma alt ölçeği ön test-son test puanları arasında istatistiksel olarak anlamlı bir farkın olup olmadığı ilişkili iki ölçüm setine uygulanan Wilcoxon İşaretli Sıralar Testi ile araştırılmış ve elde edilen sonuçlara ilişkin bulgular Tablo 10'da gösterilmiştir.

Tablo 10. Deney Grubundaki Üniversite Öğrencilerinin Stresle Başaçıkma Tutumları Ölçeğinin Kabul Bilişsel Yeniden Yapılanma Alt Ölçeği Ön test-Son test Puanlarına İlişkin Wilcoxon İşaretli Stralar Testi Sonuçları

\begin{tabular}{llcllll}
\hline Gruplar & Sıra İşareti & $\mathrm{n}$ & Sıra ortalaması & Sıra toplamı & $\mathrm{z}$ & $\mathrm{p}$ \\
\hline Deney & Negatif Sıra (-) & 4 & 3.63 & 14.50 & -2.775 & .006 \\
& Pozitif Sıra (+) & 12 & 10.13 & 121.50 & & \\
& Nötr $(=)$ & 2 & & & & \\
\hline
\end{tabular}

* Negatif sıralar temeline dayalı

Tablo 10' da verilen Wilcoxon İşaretli Sıralar Testi sonuçlarına göre deney grubundaki üniversite öğrencilerinin kabul bilişsel yeniden yapılanma düzeylerinin (puanlarının), Stresle Başa Çıkma Yaratıcı Drama Programı'na (SBYDP) katılmadan önceki ve programa katıldıktan sonraki puanları arasında anlamlı bir farklılık olduğu görülmektedir $(\mathrm{z}=-2.775, \mathrm{p}<0.05)$. Fark puanlarının sıra toplamı dikkate alındığında, gözlenen bu farkın son test puanı lehine olduğu görülmektedir. Bu sonuçlar denenceyi desteklemekte ve SBYDP'nin, üniversite öğrencilerinin SBTÖ-Kabul bilişsel yeniden yapılanma alt ölçeği düzeylerinin (puanlarının) artmasında etkili olduğunu göstermektedir denilebilir.

\section{Öğrenci Görüşme ve Etkinlik Değerlendirme Formundan Elde Edilen Nitel Verilerin Çözümlemesi}

Katılımcıların "Öğrenci Görüşme ve Etkinlik Değerlendirme Formu” una verdikleri açık uçlu yanıtlar içerik analizi ile çözümlenmiştir. İçerik analizinden elde edilen veriler Tablo 11'de yer almaktadır. Bunun yanı sıra aşağıda bu forma yanıt veren örnek katılımcı görüşleri de sunulmuştur. 
Tablo 11. “Öğrenci Görüşme ve Etkinlik Değerlendirme Formu” ndan Elde Edilen Nitel Veriler

\begin{tabular}{|c|c|c|}
\hline \multicolumn{3}{|l|}{ Öğrenci Görüşme ve Etkinlik Değerlendirme Formu } \\
\hline & $\mathbf{N}$ & $\%$ \\
\hline \multicolumn{3}{|c|}{$\begin{array}{l}\text { 1. Yaşamınızdaki stres ile baş etme yollarınız neler/Bu projeye } \\
\text { başlamadan önce stres ile nasıl baş ediyordunuz? }\end{array}$} \\
\hline a. Başkalarıyla konuşma & 18 & 100 \\
\hline b. Uyumak & 12 & 66.7 \\
\hline c. Kendi kendini sakinleştirmeye çalışmak & 5 & 27.8 \\
\hline d. Olumlu düşünmek & 6 & 33.3 \\
\hline e. Yalnız kalmak & 5 & 27.8 \\
\hline f. Ağlamak & 5 & 27.8 \\
\hline g. Müzik dinlemek & 18 & 100 \\
\hline h. Yürüyüş yapmak & 18 & 100 \\
\hline I. Spor yapmak & 14 & 77.8 \\
\hline i.Dua etmek & 3 & 16.7 \\
\hline j. Komik birşeyler izlemek & 12 & 66.7 \\
\hline k. Görmezden gelmek & 4 & 22.2 \\
\hline \multicolumn{3}{|c|}{ 2. Bu projeye katıldıktan sonra stresle nasıl baş ediyorsunuz? } \\
\hline a. Herkesin stres yaşadığının farkına vararak & 11 & 61.1 \\
\hline b. Empati kurmayı öğrenerek & 7 & 38.9 \\
\hline c. Olumlu düşünerek & 15 & 83.3 \\
\hline d. Sorunu doğru analiz ederek & 4 & 22.2 \\
\hline e. Başkalarıyla konuşarak & 8 & 44.4 \\
\hline f. Doğru nefes alıp verme egzersizlerini yaparak & 15 & 83.3 \\
\hline g. Gevşeme egzersizlerini kullanarak & 12 & 66.7 \\
\hline h. "hayal kurma" yı kullanarak & 4 & 22.2 \\
\hline \multicolumn{3}{|c|}{ 3. Projeye katılmadan önceki beklentilerinize ulaşabildiniz mi? } \\
\hline Evet & 16 & 88.9 \\
\hline Hayır & 2 & 11.1 \\
\hline
\end{tabular}

4. Projeye katılmadan önceki beklentileriniz nelerdi?

Evet diyenlerin yanttları:

$\begin{array}{llll}\text { a. Eğlenceliydi } & 8 & 44.4\end{array}$

$\begin{array}{lll}\text { b. Özgüvenimi arttırdı } & 6 & 33.3\end{array}$

$\begin{array}{lll}\text { c. Rahatlamış hissettim } & 7 & 38.9\end{array}$

$\begin{array}{lll}\text { d. Sosyalleşme sağladı } & 4 & 22.2\end{array}$

$\begin{array}{lll}\text { e. Stresle başa çıkmanın farklı yollarını kullanmayı öğretti } & 9 & 50.0\end{array}$

f. Diğer insanların olaylara farklı bakış açılarının olduğunu gösterdi $\quad 5 \quad 27.8$

Hayır diyenlerin yanıtları

a. Alışkanlıklarımı değiştiremiyorum $\quad 2 \quad 11.1$

b. Farkındalık kazandım $\quad 2 \quad 11.1$ 
5. Projeye katılma konusunda çevrenizdeki tanıdıklarınıza neler önerirsiniz?

18

100

Tavsiye ederim

\begin{tabular}{lll} 
a. Empatiyi geliştiriyor & 4 & 22.2 \\
\hline b. Özgüveni geliştiriyor & 5 & 27.8 \\
\hline c. Farkındalık kazandırıyor & 3 & 16.7 \\
d. Stres yaratan durumdan uzaklaştırıyor & 4 & 22.2 \\
\hline e. Rahatlamayı sağlıyor & 4 & 22.2 \\
\hline f. Farklı bakış açılarını görmeyi sağlıyor & 12 & 66.7 \\
\hline g. Eğlenceli bir ortamda bulunmayı sağlıyor & 7 & 38.9 \\
TOPLAM & 18 & 100 \\
\hline
\end{tabular}

Aşağıda SBYDP'ye katılan katılımcıların “Öğrenci Görüşme ve Etkinlik Değerlendirme Formu" na verdikleri yanıtlardan bazı örnekler yer almaktadır.

Örnek 1: "Eğlenirken de öğrenilebileceğini bire bir yaşadım." (4. Soruya verilen yanıt, Kız, 21 yaşında)"

Örnek 2: "Meditasyon gibi uzanıp nefes alıp vererek kendimi güzel bir yerde hayal ederek baş ediyorum.” (2. Soruya verilen yanıt, Kız, 21 yaşında )

Örnek 3: "Daha sakinim. Birşeylere vurmaya çalışmıyorum artık. Bir müzik açıp uzanarak sakinleşiyorum.” (2. Soruya verilen yanıt, Erkek, 22 yaşında)

Örnek 4: "PDR öğrencileri bu projeye katılmadan mezun olmamalı. Perspektif geliştirmek için super bir proje.” (5. Soruya verilen yanıt, Erkek, 22 yaşında)

Örnek 5: "Bu projeye katıldıktan sonra kendimi daha özgüvenli hissettim. Arkadaşlarımla birlikte tiyatro kursuna yazıldık." (3. Soruya verilen yanıt, kendini çekingen olarak ifade eden bir kız öğrenci, 22 yaşında)

Örnek 6: "Daha "insanca" tepkilerle stresimle başa çıkmaktı beklentim. Çevremdekileri üzmeden, onları kırmadan. Buna ulaştığımı düşünüyorum.” (4. Soruya verilen yanıt, Kız, 21 yaşında)

Örnek 7: "Bu projeye katıldıktan sonra stresin kaynağı hakkında düşünmeye ve onu çözmeye başladım.” (2. Soruya verilen yanıt, Erkek, 22 yaşında)

Örnek 8: "Beklentilerime ulaştım çünkü stresle nasıl baş edeceğimi bilmiyordum, şimdi ise stresin kaynağı üzerinde düşünüp kendimi kontrol edebiliyorum.” (4. Soruya verilen yanıt, Erkek, 22 yaşında)

Örnek 9: "Stres her zaman beni avucuna alır istediği gibi kullanırdı. Ama artık stresle başa çıkarken stresin kaynağını bulup çözerim ve kendimi eğlendirecek şeyler bulurum. Ayrıca strese giren bir ben değilim bunun farkındayım.” (2. ve 3. Sorulara verilen yanıtlar, kız, 21 yaşında).

$\mathrm{Bu}$ görüşler yaratıcı drama çalışmalarından sonra katılımcıların stresi tanıma, tanımlama ve stresle başa çıkma konularında daha olumlu görüş bildirdiklerini göstermektedir. Bu görüşler nicel sonuçlarla benzerlik göstermektedir. 


\section{Sonuç ve Öneriler}

SBYDP'ye katılan deney grubu üniversite öğrencilerinden elde edilen bulgular incelendiğinde:

1. SBYDP'nin uygulandığ 1 deney grubunda yer alan üniversite öğrencilerinin SBTÖ alt ölçeği-aktif planlama ve kabul bilişsel yeniden yapılama ön test-son test puan ortalamalarının arttığ1; kaçma-soyutlama 2 alt ölçeğinin ön test-son test puan ortalamalarının ise azaldığı görülmektedir. Yani SBTÖ-Aktif planlama, Kabul bilişsel yeniden yapılama ve kaçma soyutlama-2 alt boyutunda deney grubunun lehine anlamlı farklılıklar bulunmuştur. Bu sonuç programa katılan üniversite öğrencilerinin stresle baş etmede aktif planlama süreçlerini, kabul bilişsel yeniden yapılama ve kaçma soyutlama 2 süreçlerini daha doğru kullanmaya başladıkları biçiminde yorumlanabilir.

2. SBTÖ-Dış yardım arama, Dine sığınma, Kaçma soyutlama 1 ölçümlerinde ise istatistiksel olarak anlamlı farklılıklar bulunmamıştır. Ancak istatistiksel olarak anlamlı farklılık bulunmasa bile deney grubunun alt ölçek puanlarında ön testten son teste doğru bazı değişimlerin olduğu görülmektedir. Bu alt ölçeklerden elde edilen puanların aritmetik ortalamaları incelendiğinde ise dine sığınma alt ölçeğinde herhangi bir değişiklik olmadığı; dış yardım arama alt ölçeğinde az bir artışın olduğu ve kaçma-soyutlama 1 alt ölçeğinde de bir miktar azalma olduğu dikkat çekmektedir. Konuyla ilgili alan yazın incelendiğinde bunun nedeni olarak; araştırmada uygulanan SBYDP stresle başa çıkma becerilerinin birçok boyutunu ele almıştır. Ancak uygulamaların dokuz haftadan daha fazla sürdürülmesinin gerekli olduğu gözlenmiştir. Bu durum çeşitli araştırmalarla da desteklenmektedir; Lyon (1991, Aktaran: Kavalc1, 2001) tarafından yapılan araştırmadaki eğitici programın başarılı olması için grupların altı haftadan uzun olması hatta bir dönemin tümünü kapsaması gerektiğini belirtmektedir. Benzer şekilde farklı konulardaki birçok araştırma da baş etme becerilerinin yapıcı bir şekilde geliştirilebilmesi için tüm yıla dağıtılmış eğitim seanslarının yaygınlaşmasıyla mümkün olacă̆ 1 ifade edilmiştir (Johnson ve Johnson, 2004; Woody, 2001; Scott, 2003; Akt. Güner, 2007). Öğrencilerin otomatik alışkanlık modelleri haline gelene kadar süreci üst üste tekrar etmeye ihtiyaçları olduğu araştırmalarda vurgulanmaktadır (Johnson ve Johnson, 2004). Bundan dolayıdır ki sadece dokuz haftalık bir çalışma, yapıcı stresle baş etme becerilerinin yerleşmesi için yeterli olamayabilir.

Yukarıdaki bulgular ve sonuçlara dayalı olarak; stresle baş etme becerileri için yaratıcı dramaya bir yöntem olarak rehberlik programlarının içinde yer verilebileceği, yaratıcı drama ile stresle baş etme becerilerini geliştirici çalışmaların bütün yaş grupları ile uygulanabileceği, üniversite öğrencileri ile yapılacak farklı kişisel-sosyal becerileri kazanmasında yaratıcı dramadan yararlanılabileceği önerilebilir.

\section{Kaynakça}

Acar, N. V. (1995). Grupla psikolojik danışma ilke ve teknikler. Ankara: Yeni Doğuş Maatbası.

Adıgüzel, H. Ö. (1993). Oyun ve yaratıcı drama ilişsisi. Yayınlanmamı̧̧ yüksek lisans tezi. Ankara Üniversitesi Eğitim Bilimleri Enstitüsü, Ankara.

Adıgüzel, H. Ö. (1994). Eğitimde yeni bir yöntem ve disiplin: yaratıcı drama. I. Eğitim Bilimleri Kongresi 2830 Nisan 1994 içinde (s. 522-533). Çukurova Üniversitesi Eğitim Fakültesi, Adana.

Adıgüzel, H. Ö. (2006) Yaratıcı drama kavramı, bileşenleri ve aşamaları. Yaratıcı Drama Dergisi. 1(1), 17-27.

Akfirat, F. (2002). Bireysel farklılıkları olan çocuklar için drama lideri farklılıklar yaratabilir: İlköğretimde engelli çocuklarla yaratıcı drama. N. Aslan (ed), İlköğretimde drama ve tiyatro. Türkiye 4. Drama Liderleri Buluşması ve Ulusal Drama Semineri. Ankara: Oluşum Tiyatrosu ve Drama Atölyesi.

Akfirat, F. Ö. (2006). Social competence, social skills and creative drama. Yaratıcı Drama Dergisi, 1(1), 39-58.

Baltaş, A. ve Baltaş Z. (1997). Stres ve başa çıkma yolları (16. Baskı). İstanbul: Remzi Kitabevi.

Barnes, M. K. (1998). Kids on the campaign trail: process drama,social studies and ssessment in the elementary classroom. Research in Drama Education: The Journal of Applied Theatre and Performance, 4 (2), 295-295. 
Davies, D. G. (1984). Utilization of creative drama with hearing-impaired youth. Volta Review, 86 (2), 106-13.

Fulford, J., Hutchings, M., Ross,A., \& Schmitz, H. (2001). İlköğretimde drama (Çev. Küçükahmet, L., Borçbakan, H.,\& Karamanoğlu, S.S.). Ankara: Nobel Yayınları.

Gönen, M. (2001). Özürlü çocukların eğitiminde drama. N. Aslan (Ed). Dramaya çok yönlü bakış. (s. 59-64). Ankara: Oluşum Tiyatrosu ve Drama Atölyesi.

Gönen, M. (2002). Çocuk eğitiminde drama. İstanbul: Epsilon Yayıncılık.

Güner, İ. (2007). Çatışma çözme becerilerini gelişstirmeye yönelik grup rehberliğinin lise öğrencilerinin saldırganlık ve problem çözme becerileri üzerine etkisi. Yayımlanmamış doktora tezi, İnönü Üniversitesi Sosyal Bilimler Enstitüsü, Malatya.

Himmetoğlu, B. ve Kırel Ç. (1994). Stres yönetimi. Eskişehir: Anadolu Üniversitesi Yayınları.

Johanian, S. (1997). Building bridges of understanding with creative drama strategies: An introductory manual for teachers of deaf elememtary school students.

Johnson, David W., Johnson, Roger. T. (2004). Implementing the teaching students to be peacemakers program. Theory Into Practice, (43), 1, 68-79.

Kavalcı, Z. (2001). Çatışma çözme becerileri eğitimi programının üniversite öğrencilerinin çatışma çözme biçimleri üzerindeki etkisi. Yayımlanmamış yüksek lisans tezi, Hacettepe Üniversitesi Sosyal Bilimler Enstitüsü, Ankara.

Mocan, G. (1987). Stresle oluşan psikosomatik hastalıklar. Stres Yönetimi Semineri. Türkiye Sanayi Sevk ve İdare Enstitüsü (TÜSSIDE) 25-26 Aralık 1987. Kocaeli.

Morganett, R. S. (2005). Yaşam becerileri ergenler için grupla psikolojik danışma uygulamaları. Ankara: PegemA Yayıncilik.

McCaslin, N. (1990). Creative drama in the classroom. (5. Edt.). London:Longman.

Öner N, Le Compte A. (1983). Durumluk sürekli kaygı envanteri el kitabı. İstanbul: Boğaziçi Üniversitesi Yayınlar1, 1-26.

Özmen, A. (2006). Öfke ile başaçıkma uygulamalı grup rehberliği programları dizisi. (Ed.Uğur Öner). Ankara: Nobel Yayıncilik.

Özbay, Y., ve Şahin, B. (1997). Stresle başaçıkma tutumları envanteri: geçerlik ve güvenirlik çalışması [Inventory of coping with stress attitudes: A validity and reliability study]. IV. Ulusal Psikolojik Danışma ve Rehberlik Kongresi'nde sunulan bildiri. Ankara: 1-3 Eylül 1997 Guidance and Psychological Counseling Congress, Ankara University, Ankara.

Peter, M. (1994). Drama for all. London: David Fulton Publishers.

Rosch, P. S. (1986). Stres addiction: causes, conseqoences and cures, stress and tt's managements. New York.

San, İ. (1996). Yaratıcıllı̆ı̆ geliştiren bir yöntem ve yaratıcı bireyi yetiştirme bir disiplin: eğitsel yaratıcı drama. Yeni Türkiye Dergisi, (7)148-160.

San, İ. (2002). Eğitimde yaratıcı drama 1985-1995 yazılar, (Edt.Ö.Adıgüzel). Ankara: Naturel Yayıncılık.

San, İ. (2003). Dramada temel kavramlar: çocukta yaratıcılık ve drama. Eskişehir: Anadolu Üniversitesi Yayinları.

Somers, J. (2008). Drama ve iyi oluş: anlatı kuram ve ruh sağlı̆̆ bilincini arttırmada interaktif tiyatronun kullanımı, Yaratıcı Drama Dergisi, 1 (5), 115-141.

Şahin, N. H., Durak, A. (1995) Stresle başaçıkma tarzları ölçeği: üniversite öğrencileri için uyarlanması. Türk Psikoloji Dergisi, 10 (34), 56-73.

Tutar, H. (2000). Kriz ve stres ortamında yönetim. İstanbul: Hayat Yayınları.

Üstündağ, T. (1994). Günümüz eğitiminde dramanın yeri. Yaşadıkça Eğitim Dergisi, (37), 7-10.

Woody, D. (2001). A comperhensive school-based conflict-resolution model. Children \& School, 23 (2), 115.

Yılmaz, N. (2004). Öfke ile başa çıkma eğitiminin ve grupla psikolojik danışmanın ergenlerin öfke ile başa çıkabilmeleri üzerindeki etkileri. Yayımlanmamış doktora tezi, Hacettepe Üniversitesi Sosyal Bilimler Enstitüsü, Ankara. 


\section{Ek 1: Atölye Planı Örnekleri}

\section{Üçüncü Oturum}

Süre: $45+45$ dakika

Yöntem ve Teknikler: Yaratıcı drama (rol oynama, doğaçlama, donuk imge).

Araç-Gereç: 3 adet Minder, CD çalar, (müzik parçası, şarkıcı; Don Omar- müzik eseri; Danza Kuduro, 2010), 2 adet A4 kâğıdı, 2 adet büyük resim kağıdı, 2 kutu boya kalemi, hayvanların doğadaki fotoğrafları (15 taneden fazla avlanma içerikli hayvan fotoğrafları), drama atölyesindeki malzemeler.

\section{Kazanımlar:}

1. Stresin anlamını kavrar.

2. Strese yol açan nedenleri kavrar.

3. Strese gösterilen olumlu-olumsuz tepkileri hakkında bilgi sahibi olur.

4. Stres kaynağı olan olumsuz düşünce tarzları hakkında bilgi sahibi olur.

\section{$\underline{\text { Sürec }}$}

\section{A. Isınma-Hazırlık}

\section{Etkinlik}

Lider öğrencilere mekân içinde serbestçe yürümelerini söyler. Lider aşağıdaki ifadeleri söyler. Tek tek üyeler herhangi bir nesnenin yarattığı sorunlarla başa çıkmaya çalışırlar.

- sıkışmış kavanoz kapağ

- takılmış bir fermuar

- dar bir çizmeyi çıkarmak

- kapağı sıkışmış bir çekmeceyi açmaya çalışmak

- elleriniz paketlerle doluyken bir kapıyı açmaya çalışmak

- ağzına kadar su dolu bir bardağı dökmeden taşımak

- arabanın kapısına sıkışmış kazağın kolunu kurtarmaya çalışmak

- üst üste konmuş 10 tane kitabı düşürmeden yürümek (Ayşe Okvuran atölyesinden esinlenilmiştir).

Lider katılımcı eyleme başladıktan sonra eylemleri derinleştirmek için "uğraşıyorsunuz ama açılmıyor", "bütün kaslarınız kullanın” gibi ifadeler söyler.

\section{Etkinlik}

Lider "şimdi arabalarınıza doğru yürüyorsunuz ve bu arada arabanın anahtarlarını arıyorsunuz ama bir türlü bulamıyorsunuz" der. Lider "durun ... ve göz göze geldiğiniz ilk kişi ile eş olun" der. Eşlerden biri araç diğeri sürücü olur. Eşler ayakta dururlar. Araç gözünü kapar sürücü onun arkasına geçer. Belli hareketlerle konuşmadan aracı yönlendirir. Sırtına vurmak öne doğru yürü demektir. Kafaya vurmak dur demektir. Sağ omuza vurmak sağa dön demektir. Sol omuza vurmak sola dön demektir. Enseye vurmak geri gitmek demektir gibi. Mekânda bu şekilde gezilirken diğer çiftlere çarpmamak ve eşlerin güvenliğinden sorumlu olmak gerektiği hatırlatılır. Sonra da eşler değiştirilir.

\section{Etkinlik}

Lider grup üyelerine en yakınındaki başka bir kişiyle eş olmalarını söyler. Eşlere kolkola girmelerini söyler. Ortaya iki gönüllü alınır. Birisi kaçan birisi kovalayan olur. Kaçan kolkola girmiş eşlerden birinin koluna girdiği an diğer tarafta kalan yeni kaçan kişi olur. 


\section{Ara değerlendirme}

Lider grup üyelerine çember biçiminde yere oturmalarını söyler ve aşağıdaki paylaşımlara yer verir.

1. Oyunlar sırasında neler düşündünüz, neler hissettiniz?

2. Mekânda gözleriniz kapalı iken ve eşlerinize güvenmeniz gerektiği oyunlarda aklınızdan geçen düşünceler nelerdi?

3. Bu düşünceler stres düzeyinizi nasıl etkiledi?

4. Farklı düşünseydiniz tepkiniz nasıl olurdu?

5. Hangi oyunda daha stresli idiniz? Neden?

6. Yaşadığınız stres karşısında ne tür tepkiler verdiniz?

7. Size göre stres nedir?

\section{B. Canlandırma}

\section{Etkinlik}

Lider getirdiği farklı hayvan fotoğraflarını mekânda zemine rastgele koyar. Grup üyelerinden ikili olmalarını ve eşleriyle bu fotoğrafları gezmelerini ve en beğendikleri fotoğrafın yanında durmalarını söyler. Fotoğrafin yanında duran ikilinin bir grup olduğunu ve o fotoğraftaki şeklin aynısını sergileyeceklerini söyler. Grup üyelerine hazırlanmaları için yeterli süre verilir. Grup üyeleri fotoğraflarını donarak sergilerler ve lider her fotoğraftaki üyenin yanına giderek bir cümle ile içinde bulunduğu durumu ifade etmesini söyler.

Ardından grup üyelerine mekânda kendilerine bir yer seçmeleri, rahat bir pozisyonda oraya uzanmaları ve gözlerini kapatmaları söylenir. Lider aşağıdaki öyküyü okur:

“İlkçağlara geri döndünüz. Keskin dişli kaplanlar ve tüylü mamutlar otlaklarda dolaşıyorlar. Sizde bir kayanın tepesinde duruyorsunuz ve bir ateşin etrafında grup halinde ve deri giysiler içinde bir grup insanı izliyorsunuz. Isınıyorlar ve o gün avladıklarını yiyorlar. Kadınlar çocukları besliyorlar. Hayat çok tehlikeli olduğu için, sürekli tetikte olmak zorundalar. Evleri şu anda sizin üzerinde durduğunuz kayanın altındaki bir mağara. Ta uzaklarda, günümüzdeki normal bir kaplandan daha büyük, keskin dişli bir kaplan ateşin etrafinda yemeklerini yiyen insanların yediklerinin kokusunu alıyor. Kurt gibi aç olan bu kaplan insanlara doğru koşmaya başlıyor. Ateşin çevresindeki insanlara kükrüyor. İnsanların kalpleri korkuyla doluyor. Hayatları tehlikede. Ne yapmalılar? Kendilerini korumak için ne yapabilirler? Sadece basit mızrakları var ki bu da asla güçlü bir kaplana karşı koyamaz. Kendilerini korumak için sadece iki seçenekleri var. Sahip oldukları silah ile savaşmak ya da mağaralarını kaçıp saklanmak. Savaşabilirler ya da kaçabilirler. Savaş ya da kaç.

Kayanın tepesinden bakarken; ilk çağ insanlarının panik içinde olduklarını görebilirsiniz. Kalpleri koşmak, tırmanmak ve savaşmak için ayaklarına daha fazla kan ve oksijen gönderebilmek için daha hızlı çarpmakta. Daha iyi görebilmek için gerekli olan ışık girebilsin diye göz bebekleri sonuna kadar açılmış. Avuçları terliyor. Olağanüstü enerji veren adrenalin damarlarına pompalanmakta. Vücuttaki ve diğer değişimler stres tepkileri diye adlandırlır. Vücut tehdit ve tehlikeye savaşmak ya da kaçmaya hazır olarak tepki verir ki bu da mağara insanın kendini kurtarması için var olan yalnız iki seçenektir. Stres tepkileri onların vücut fonksiyonlarını en yüksek seviyeye çıkararak onlara yardımcı olur. Tehlike ortaya çıkarsa stres tepkileri de oluşur.

İnsanları mağaralarına kaçışırken, kayalara tırmanırken, mızraklarına sarılırken ve kaplanı uzaklaştırmak için ateşi hızlandırırken görebilirsiniz. Ateşin tehlikeli olduğunu bilen kaplan kararsızdır. Mağara insanları şimdi neler yapmalılar ......". (Morganett, 2005 değiştirilerek alınmıştır).

\section{Etkinlik}

Lider grup üyelerine 1 ve 2 olarak saymalarını söyler ve $1^{\prime}$ ler bir araya 2'ler bir araya gelirler. Lider 1'lerden sonu insanların kaçması ile biten yukarıdaki öyküyü canlandırmaları; 2'lerden sonunun savaşma ile bitmesi yönergesini verir. Canlandırmalara hazırlanırken drama atölyesindeki her malzemenin kullanılabileceğini hatırlatılır. Gruplara hazırlanmaları için yeterli süre verilir, sırayla canlandırmalar izlenir. 


\section{Etkinlik}

Lider her grubun kendi grup üyeleriyle bir araya gelerek günlük yaşamları içerisinde yukarıdaki durumların günümüzde (modern çağda) ortaya çıktığı biçimiyle yani sosyal grupların başından geçen stresli durumların neler olabileceğini düşünmelerini (bunun için çevrelerinde tanıdıkları kişilerin başına gelen olayları veya yaşantıları hatırlamaları) ve birbirlerine anlatmalarını söyler. Grup üyeleri tarafından beğenilen bir olay grup üyelerince canlandırılmak üzere seçilir. Gruplara hazırlanmaları için yeterli süre verilir ve canlandırmalar izlenir.

\section{Değerlendirme}

\section{Etkinlik}

Grup üyelerine renkli kalemler ve kağıtlar dağıtılarak kağıtların mağaranın duvarı olduğunu hayal ederek günlük hayatlarını (gündelik yaşam biçimlerini) resmetmeleri istenir

Lider grup üyelerinden çember biçiminde yere oturmalarını ister ve bugünkü oturumda yapılan etkinliklerle ilgili olarak aşağıdaki soruları üyelere sorar.

1. Oyunda yaşadıklarınızla ilgili neler hissettiniz?

2. Oyundaki rolünüze nasıl hazırlandınız?

3. Oyunda aklınızdan geçen duygu ve düşünceleriniz nelerdi?

4. Benzer bir durumda kalsanız neler hisseder, düşünür ve yapardınız?

5. Stres durumlarında hangi düşünceler aklınızdan geçiyor?

\section{Beşinci Oturum}

Süre: $45+45$ dakika

Yöntem ve Teknikler: Yaratıcı drama (rol oynama, doğaçlama).

Araç-Gereç: CD çalar (bestesi Vivaldi- müzik eseri, 4 Mevsim-yaz, 1723; besteci; Rodrigo-müzk eseri; Concierto de Aranjuez, 1939; şarkıcı, Christina Aguilera-müzik eseri, Candy Man, 2007 ve şarkıc1; Shantal-müzik eseri; Disco Partizani, 2005). Drama atölyesindeki malzemeler.

\section{Kazanımlar:}

1. Bedensel yorgunluğun ne olduğununun farkına varır.

2. Stresle başa çıkma yollarından biri olan bedensel gevşeme egzersizinin aşamalarını kavrar

\section{Süreç}

\section{A. Isınma-Hazırlık}

\section{Etkinlik}

Lider tüm grubun çember biçiminde ayakta durmasını ve başlarının üzerinde bir nokta tespit etmelerini söyler. Grup üyelerinin kollarını kaldırarak en yüksek noktaya bütün kaslarıyla uzanmaya çalışmalarını söyler. En yüksek noktaya ulaşmak için parmak uçlarına kadar yükselmeleri söylenir. Lider "tamam” dediğinde grup üyeleri kendilerini serbestçe aşağı bırakır. Lider müzik eşliğinde aynı hareketleri tekrar ettirir. Lider grup üyelerine aşağıdaki yönergeleri verir.

- Sağ kolunla sağ tarafına uzanabildiğin kadar uzanınız ... uzanınız ... sonra serbest bırakın

- Sol kolunla sol tarafına uzanabildiğin kadar uzanınız ... uzanınız ... sonra serbest bırakın

- Sağ bacağınla sağ tarafına uzanabildiğin kadar uzanınız ... uzanınız ... sonra serbest bırakın

- Sol bacağınla sol tarafına uzanabildiğin kadar uzanınız ... uzanınız ... sonra serbest bırakın der. 


\section{Etkinlik}

Lider tüm grup üyelerinin mekan içerisinde serbest biçimde yürümesini söyler. Aşağıda vereceği yönergelere göre yürümeye devam etmelerini söyler.

- Bir çamur içerisinde yürüyorsunuz çamur gitgide daha da katı ve yoğun bir hal alıyor... Zorlanıyorsunuz... Çamurdan kocaman bir ayakkabınız oldu onu taşıyamıyorsunuz... Ayağınızı kaldıramıyorsunuz ve adım atmakta zorlanıyorsunuz...

- Şimdi suyun içinde yürüyorsunuz ve gitgide suya daha çok giriyorsunuz... derinleşiyor... dizlerinize çıkıyor... suyu iterek yürüyorsunuz...

- Ayakkabılarınız açıldı ve yanlarından delindi içi çamurlu suyla doldu bu şekilde yürümeye çalışıyorsunuz...

- Karşınızdan bir rüzgâr esiyor... Nefesiniz kesiliyor... ve içinizi üşütüyor...

- Çamurlu ve suyla dolu olan ayakkabılarınızı çıkarıyorsunuz... Ayaklarınız çıplak... Çok yakıcı kumların üzerinde yürüyorsunuz...

- Çıplak ayaklarınızla çakıl taşlarının üzerinde yürüyorsunuz...

- Çıplak ayaklarınızla çikolata kremasıyla kaplı bir yerde yürüyorsunuz...

- Çıplak ayaklarınızla yumuşacık çimlerin üzerinde yürüyorsunuz...

Gezimizin son durağındayız

- Ormanlık bir alana geldik... Çok yorgunuz çok yorulduk... Kendimizi bu harika doğanın kucağına bırakıyoruz... Etrafta kelebekler uçuşuyor... Uzakta bir anne ceylan ve yavrusu var... Kuşlar cıvıldaşıyor... Mis gibi çam ve çiçek kokularının içerisindeyiz... Herkes istediği gibi dinlenebilir. Gözlerinizi kapatıp buranın havasını iyice içinize çekin...

\section{B. Canlandirma}

\section{Etkinlik}

Lider grup üyelerinin kendilerine bir eş seçmesini söyler. Eşlerden birinin A, diğeri B olacağını söyler.

A'lar, işten eve yorgun gelmiştir ve bir duş alıp televizyonun karşısında tembellik yapıp ardından erkenden yatacaktır.

B'ler, eşlerinin eve gelmesini tüm gün beklemiş ve akşam eşiyle dışarı çıkıp beraber bir şeyler yapmak istemektedir.

Lider tüm grubun canlandırmalara aynı anda başlamasını ister. Lider grupların arasında gezer bir grubu belirler ve tüm grup canlandırmalarını yarıda keserek onları izler. Canlandırmalar kaldığı yerden devam eder lider tekrar grupların arasında gezer başka bir grubu belirler ve tüm grup onları izler bu şekilde canlandırmalar izlenir.

\section{Etkinlik}

Lider aşağıdaki durumları verir. Dörtlü grup oluşturarak bu durumları canlandırmalarını söyler.

1. Durum: Bir banka. Ay başıdır ve birçok müşteri o gün ödemeler, hesaplar, krediler gibi ihtiyaçları sebebiyle bankadadır.

A: Oldukça sinirli, çalıştığı banka kredi kartından yapmadığı bir harcamanın parasını almış.

B: Çok yoğun bir gün, bütün müşteriler kuyruk olmuş sıranın kendisine gelmesini bekliyor, kafasını kaşıyacak vakti yok.

C: Bankada sıranın kendisine gelmesini bekleyen sabırsız bir delikanlı çünkü işi biter bitmez kız arkadaşıyla buluşacaktır.

D: Bankanın güvenlik görevlisidir, bugünlerde bankadaki işine devam edip edemeyeceği belli olacaktır. Çünkü çalışma sözleşmesinin yenilenme zamanı gelmiştir. 


\begin{abstract}
değerlendirme yapılır.
- Canlandırmalardaki kişilerin akıllarından geçenler nelerdir?

- Canlandırmalardaki kişiler hangi duygular içerisindeydiler?
\end{abstract}

Canlandırmalar izlendikten sonra çember biçiminde ayakta durarak aşağıdaki sorularla ara

2. Durum: Bir ailenin akşam yemeğinden sonra evdeki halleri.

A: Anne, o akşam takipçisi olduğu diziyi izlemek istiyor. Dizideki yeni gelişmeleri bütün hafta merakla bekledi.

B: Baba, o akşam önemli bir maç var onu izlemek istiyor. Maçın sonucuyla ilgili bahse girdi.

C: 7 yaşında, okula bu yıl başladı öğretmenin verdiği ödevleri yapmakta zorlanıyor çünkü ödevlerini yazarken elleri çok ağrıyor. O gün yine yarına yetiştirmesi gereken çok ödevi var.

D: 15 yaşında, yarın akşam arkadaşının evindeki partiye gitmek istiyor, bunun için ailesinden izin alması gerekiyor.

Canlandırmalar izlendikten sonra çember biçiminde ayakta durarak aşağıdaki sorularla ara değerlendirme yapılır.

- Canlandırmalardaki kişilerin akıllarından geçenler nelerdir?

- Canlandırmalardaki kişiler hangi duygular içerisindeydiler?

3. Durum: Bir grup insan otobüs durağında bekliyor ama bütün otobüsler dolu geldiği için binecek yer bulamıyorlar. Bu sırada bir otobüs daha yaklaşıyor ve yine içi dolu, herkes otobüsün kapısına doğru bir hamle yapıyor.

A: Oldukça sinirli bir devlet memuru, işe geç kaldığı için müdürün kendisine kızacağını bu nedenle ilk olarak onun otobüse binmesi gerektiğini söylüyor.

B: Çok yorgun bayılmak üzere bir yaşlı adam, yaşlı olduğu için otobüse binerek bir an önce evine gidip dinlenmesi gerektiğini söylüyor.

C: Ayakta duramayacak hale gelmiş hamile bir kadın, o gün doktorla randevusu var ve randevusunu kaçırmak üzere olduğunu söylüyor.

D: Ortopedik engelli bir kadın, engellilerle ilgili önemli bir toplantıya gitmek için otobüse binmesi gerektiğini söylüyor. yapılır.

Canlandırmalar izlendikten sonra çember biçiminde oturarak aşağıdaki sorularla ara değerlendirme

- Canlandırmalardaki kişilerin akıllarından geçenler nelerdir?

- Canlandırmalardaki kişiler hangi duygular içerisindeydiler?

- Kişiler stresli olduğunda vücutları, elleri, kolları ile ne yapıyorlar?

- Siz stresli olduğunuzda neler yapıyorsunuz?

- Stresli olduğunuzda bedeninizin hareketleri neler oluyor?

- Stresli olduğunuzda rahatlamak için hangi yolları kullanıyorsunuz?

Lider grup üyelerine stresli durumlarla baş etmede kullanabilecekleri gevşeme egzersizlerinin olduğundan söz eder ve aşağıdaki egzersizleri yaptırır. 


\section{Etkinlik}

Lider herkesin yere sırtüstü uzanmasını söyler. Lider grup üyelerinden elini çırparak yönerge verdiğinde 180 derece dönmelerini söyler. Döndükten sonra herkes istediği bir biçim alır ve tekrar yönerge verildiğinde tam tersi yapılır. Bir süre yinelendikten sonra lider grup üyelerinin yavaşça nefes almalarını ve nefeslerini tutmalarını söyler. Nefes alıp tutulur ve bırakılarak nefesler ayarlanmaya çalışılır. Olduğu yerde yönerge geldiğinde bir devinim yapma ve dönme uygulaması 5 kez yinelenir. Daha sonra aynı hareketler en sonuncudan ilkine doğru yinelenir.

Bedeni germe ve gevşetme: yere uzanın, ellerinizden ve ayaklarınızdan çekildiğinizi hissetmeye çalışın... Ayaklarınızı yerden hafifçe kaldırarak nefesinizi alıp tutun ve bırakın... Bir kedi gibi yumak haline gelin... yavaşça esneyerek bedeninizi açın... Ardından ayağa kalkın ve grup üyelerinizle birlikte bir çember oluşturun... Ellerinizi parmak uçlarından bir üçgen biçiminde birleştirin... ve yukarı doğru yavaşça kaldırarak başınızın üzerine getirin... parmak ucunuzda durun... ve yine yavaşça ellerinizi indirin... dizlerinizi kırarken yere doğru eğilin... Elleriniz yüz hizasındayken kalkılıp ilk baştaki duruşa geçin.... Birkaç kez yinelendikten sonra çalışma sonlandırılır (San, 2003).

Stresle baş etmenin bir diğer yolunun da nefes ve gevşeme alıştırmaları olduğu gruba açıklanır. Öfke yaşantısının öncesinde ve öfke anında bireyin bedeninde, duygularında, düşüncelerinde ve davranışlarında ortaya çıkan değişiklikleri kontrol altına almada nefes düzenleme alıştırmasının önemli olduğu vurgulanır ve nefes düzenleme alıştırmasının nasıl yapılacağı gösterilir.

\section{Etkinlik}

\section{Nefes Düzenleme Alıştırması ${ }^{4}$}

"Rahat edebileceğiniz bir pozisyon alınız... Elinizin birini karnınızın üzerine koyabilirsiniz...Şimdi nefes alıyoruz ve nefes alırken içimizden yavaş yavaş sayıyoruz bir...iki...üç...dört duruyoruz...Nefesimizi içimizde tutuyoruz...Nefesimizi vermeye başlıyoruz ve yine nefesimizi verirken de sayıyoruz...bir...iki... üç..dört..beş. Tekrar ediyoruz... Nefes alıyoruz, nefesimizi alırken içimizden sayıyoruz... bir...iki...üç.. dört duruyoruz, nefesimizi içimizde tutuyoruz ve şimdi nefesimizi vermeye başliyoruz, nefesimizi verirken saymaya devam ediyoruz..bir...iki...üç..dört..beş../tekrar.../tekrar...Nefesimizi verirken beşe kadar, alırken dörde kadar sayıyoruz. Bu durum, nefesimizi verirken daha yavaş vermemiz gerektiği anlamına geliyor/... tekrar.../

Lider gruba nefes düzenleme alıştırmasının ardından derin gevşeme alıştırması hakkında bilgi verir. “Gevşeme alıştırması bireylerin, duygu, düşünce, davranışlar ve bedensel durum üzerinde, kendi kontrollerini artırmayı amaçlayan bir tekniktir. Bu teknik genellikle bireylerde gerginlik yaratan durumlarda kendi bedenlerinde ortaya çıkan gerginliklere dikkatlerini yönelterek, bu gerginlikleri azaltmak ve kontrol altına almak amacıyla kullanılmaktadır. Öfke yaratan durumlar karşısında, öfke yaşantısı öncesinde, öfke yaşantısı anında ve öfke yaşantısından sonra, bireylerde birçok bedensel gerginlik ortaya çıkmaktadır. Bu gerginlikleri kontrol etmek öfkeyle başa çıkmada önemlidir” şeklinde açıklamasını yapar.

\section{Etkinlik}

Derin Gevşeme Alıştırmas1 $1^{5}$

Gevşeme alıştırması herkesin kendi kendine kullanabileceği bir tekniktir. Şimdi bu tekniğin nasıl uygulandığını göreceğiz. Başlangıçta zor ve uzun görünmesine karşın, birkaç uygulamadan sonra otomatik bir hal aldığını göreceksiniz.

4 Özmen, A. (2006) Öfke ile başa çıkma uygulamalı grup rehberliğ programarı dizisi. Editör: Uğur Öner, Ankara: Nobel Yayın Dağıtım.

5 Yılmaz, N.(2004). Öfke ile başa çıkma eğitiminin ve grupla psikolojik danışmanın ergenlerin öfke ile başa çıkabilmeleri üzerindeki etkileri. H.Ü. Sosyal Bilimler Enstitüsü Öfke ile başa çıkma eğitiminin ve grupla psikolojik danışmanın ergenlerin öfke ile başa çıkabilmeleri üzerindeki etkileri. Yayımlanmamış doktora tezi, Hacettepe Üniversitesi Sosyal Bilimler Enstitüsü, Ankara. Doktora Tezi. 
Bu alıştırmanın amacı, size bedeninizdeki gerginlik ve gevşeme durumları arasındaki farkı göstermek ve nasıl gevşeyebileceğinizi öğretmektir. Bu alıştırma süresince, gerginlik ve gevşeme hareketleri arasındaki farka dikkat edin. Önemli olan, kaslarınızdaki gerginliği fark edebilmeniz ve bu gerginliği kendi denetiminizle gevşetebilmenizdir. Şimdi rahat bir biçimde uzanın ve gözlerinizi kapatın ve gevşeyebildiğiniz kadar gevşeyin.

İlk olarak sizden el ve omuz kaslarınıza dikkat etmenizi istiyorum. Bu kaslarınızı, ellerinizi yumruk yaparak gerin... Şimdi yumruklarınızı sıkabildiğiniz kadar sıkın... daha çok... daha çok sıkın... Ellerinizin ve kollarınızın ön tarafındaki gerginliği hissedin... Gerginliği iyice hissedin ve rahatlayın... Kaslarınızın gerginliği ve gevşekliği arasındaki farka dikkat edin. Ve kendinizi bırakma hissine devam edin... Kaslarınızdaki gevşekliğin ve rahatlı̆̆ın nasıl olduğuna dikkat edin. Ve yalnızca serbest bırakma hissine... ve derin bir biçimde gevşemeye devam edin... Hiç gerginlik yok... Tamamen gevşeksiniz... ve şimdi kollarınızın üst ön kısmındaki kaslar... kollarınızı dirseklerinizden bükün ve bileklerinizi omuzlarınıza değdirmeye çalışarak, bu kaslarınızı gerin... şimdi bileklerinizi omuzlarınıza değdirmeye çalışarak bükün... daha sert... iyice sert... bileklerinizdeki gerginliği hissedin... gerginliği hissedin... ve yavaşça gevşeyin... kollarınızı düzeltin... kollarınızı yana serbestçe bırakın ve bileklerinizdeki gerginliğin tamamen kaybolmasına izin verin... ve tekrar kaslarınızın gerginlik ve gevşekliği arasındaki farka dikkat edin... serbest bırakma hissine devam edin... kaslarınızı rahatlatmaya devam edin ve serbest bırakın... daha çok gevşediklerini hissedin... bütün bedeninize dikkat edin... hiçbir gerginlik yok... tamamen gevşeksiniz... rahatsınız...

Ve şimdi kollarınızın üst arka kısmındaki kaslar... kollarınızı olabildiğince düz ve sert, öne doğru uzatarak kaslarınızı gerebilirsiniz... şimdi... kollarınızı uzatın... sert... iyice sert... gerginliği hissedin... bu kaslarınızdaki gerilmeyi hissedin... devam edin... ve yavaşça gevşeyin... kollarınızı gevşetin... kaslarınızı gevşetin ve gerginliğin kaybolduğunu hissedin... ve gerginlikle gevşeme arasındaki farka odaklaşın... ve serbest bırakma hissine devam edin... kaslarınızı iyice gevşemeye bırakın... ve kollarınızın bütün kaslarını gevşemeye ve rahatlamaya bırakmaya devam edin... kollarınızın daha derince gevşemesine izin verin... ve serbestliği hissetmeye devam edin... tamamen gevşeksiniz... hiç gerginlik yok...

Ve şimdi omuz kaslarınız... Omuzlarınızı yukarı doğru çekerek, boynunuza yaklaştırın... yukarı... daha yukarı... iyice yukarı... sırtınızın üst kısmındaki ve omuzlarınızdaki gerilmeyi hissedin... gerginliği hissedin... ve gevşeyin... yalnızca omuzlarınızın düşmesine firsat verin... ve omuzlarınızdaki gerginliğin kaybolduğunu hissedin... ve tekrar omuzlarınızdaki gerginlikle gevşeme arasındaki farka bakın... ve bırakma hissine devam edin... daha da derin biçimde gevşeyin...

Ve şimdi boyun kaslarını... bu kaslarınızı, başınızı yapabildiğiniz kadar çok geriye eğerek gerin... şimdi başınızı geriye doğru iyice eğin... daha fazla... daha fazla... boynunuzdaki gerginliği hissedin... gerginliği hissedin... gerilmeyi hissedin... ve yavaşça gevşeyin... boynunuzu gevşetin... tamamen serbest bırakın... ve tüm gerginliğin kaybolduğunu hissedin... boyun kaslarınızın gevşemesine ve rahatlamasına izin verin... ve bırakma hissine devam edin... yavaşça gevşeyin... boynunuzun daha derince gevşemesine izin verin... boynunuzda hiç gerginlik yok... bütün bedeninize dikkat edin... hiçbir gerginlik yok... tamamen gevşeksiniz...

Şimdi alnınızdaki kaslar... soru sorar gibi, kaşlarınızı yukarı kaldırarak, bu kaslarınızı gerebilirsiniz... şimdi kaşlarınızı yukarı kaldırın... daha yukarı... iyice yukarı... alnınızdaki gerginliği hissedin... ve yavaşça gevşeyin... kaşlarınızı yavaşça aşağı bırakın... ve gevşeyin... alnınızı düzleştirin... ve tüm kaslarınızı gevşemeye ve rahatlamaya bırakın... alnınızda hiçbir gerginlik yok... yalnızca serbest bırakmaya devam edin... çok kolay... çok hoşnut edici... serbest bırakmaya devam edin... kaslarınızın gevşemesine ve rahatlamasına izin verin... ve şimdi kaşınızdaki kaslar... bu kasları yapabildiğinizce sertçe yüzünüzü asarak gerebilirsiniz... şimdi kaşlarınızı birbirine yaklaştırın ve çatın... sert... daha sert... iyice sert... yüzünüzdeki gerginliği hissedin... gerilimi hissedin... ve yavaşça gevşeyin... yüzünüzü rahat bırakın... büsbütün gevşeyin... kaslarınızın gevşemesine izin verin ve tamamen serbest bırakın... yüzünüzden gerginliğin kaybolduğunu hissedin ve bırakma hissine devam edin... kaşlarınızda hiçbir gerginlik yok... tüm bedeninize dikkat edin... hiç gerginlik yok... tamamen gevşeksiniz... 
Ve şimdi gözlerinizin etrafındaki kaslarınız... bu kasları, gözlerinizi sımsıkı kapatıp sıkarak gerebilirsiniz... şimdi gözlerinizi yumun... daha sıkı... iyice sık1... gözlerinizin etrafındaki gerginliği hissedin... ve gevşeyin... gözlerinizi gevşetin ve göz kapaklarınızı hafifçe kapalı tutun... göz kapaklarınızda hiçbir gerginlik yok... kaslarınızı tamamen gevşetmeye devam edin... yalnızca rahatlamaya devam edin... gözlerinizin etrafında hiçbir gerginlik yok... tüm bedeninize dikkat edin... ellerinizde, kollarınızda, omuzlarınızda, boynunuzda, yüzünüzde hiç gerginlik yok..

Ve şimdi de çene kaslarınız... çenenizi, dişlerinizi yapabildiğiniz kadar sert biçimde bastırarak gerebilirsiniz. Şimdi dişlerinizi sıkın... daha sıkı... çenenizdeki gerginliği hissedin... gerginliği hissedin.... Ve yavaş̧̧a gevşeyin... çenenizi gevşetin... dişlerinizin arasında basınç kalmayacak biçimde, dişlerinizi yavaşça ayırın... çenenizde hiçbir gerginlik yok... ve rahatlama hissine devam edin... çenenizdeki gerginlik ve gevşeme arasındaki farka dikkat edin... serbest bırakma hissine devam edin... çenenizi gevşetin... hiçbir gerginlik yok... tamamen gevşeksiniz...

Ve şimdi dil ve boğazınızdaki kaslar... Bu kaslarınızı, dilinizin ucunu üst damağınıza koyarak gerebilirsiniz... şimdi dilinizin ucunu, yapabildiğiniz kadar sert, yukarı bastırın. Sertçe bastırın... daha sert... dilinizdeki ve boğazınızdaki gerginliği hissedin... gerginliği hissedin... gerginliği hissedin... devam edin... ve yavaşça gevşeyin... dilinizi aşağı indirin, serbest bırakın ve tamamen gevşeyin... dil ve boğazınızda hiçbir gerginlik yok... serbest bırakma hissine devam edin... dil ve boğazınızı gevşetin... çok daha derin... dilinizi ağzınızın içinde hareketsiz ve gevşek bırakın....

Şimdi de dudaklarınızdaki kaslar... bu kaslarınızı, dudaklarınızı sıkıca birbirine bastırarak gerebilirsiniz... şimdi dudaklarınızı birbirine bastırı... daha şiddetli... gerginliği hissedin... gerginliği hissedin... ve... yavaş̧̧a gevşeyin... dudaklarınızı yavaş̧̧a gevşetin... dudaklarınız hafifçe birbirine değsin... aralarında hiç gerginlik yok... ve serbest bırakma hissine devam edin... kaslarınızı gevşek ve rahat bırakmaya devam edin... yüzünüzün tümünü daha da derin bir biçimde serbest bırakın... yüzünüzde hiçbir gerginlik yok... tamamen gevşeksiniz...

Ve şimdi de göğüs kaslarınız... bu kaslarınızı, yapabildiğiniz kadar derin biçimde nefes alarak gerebilirsiniz... şimdi çok derin bir nefes alın... ve nefesinizi tutun... tutun... göğsünüzdeki gerginliği hissedin... ve yavaşça nefesinizi bırakın... ve tamamen gevşeyin... serbest bırakmanın verdiği iç rahatlığ hissedin... şimdi rahatça nefes alıp vermeye devam edin... ve göğsünüzdeki gevşekliği hissetmeye çalışın... ve her defasında soluğunuzu biraz daha gevşek verin... göğsünüzde hiçbir baskı yok... her nefes verişte biraz daha gevşediğinizi, rahatladığınızı hissedin...

Ve şimdi de midenizin etrafındaki kaslar... bu kaslarınızı, bir yumruk darbesi almaya hazırlanır gibi, midenizin kaslarını sıkarak gerebilirsiniz... şimdi mide kaslarınızı sıkın... sıkı... daha sıkı... midenizin çevresindeki gerginliği hissedin... şimdi rahat bırakın... mide kaslarınızda hiçbir gerginlik yok... kaslarınız yumuşak ve gevşek... midenizin çevresindeki tüm gerginliğin kaybolmasına izin verin... ve kaslarınızın gerginlik ve gevşeme durumları arasındaki farka dikkat edin... serbest bırakma hissine devam edin... mide kaslarınızda hiçbir gerginlik yok... mide kaslarınızı daha da rahatlatmaya devam edin...

Ve şimdi kalçalarınızdaki kaslar... bu kasları, kalçalarınızı yapabildiğiniz kadar sıkarak gerebilirsiniz... şimdi kalçalarınızı sıkın... sıkı... daha sıkı... kalçalarınızdaki gerginliği hissedin... gerilimi hissedin... ve yavaş̧a gevşeyin... kalçalarınızı gevşetin ve gerginliğin kaybolduğunu hissedin... ve kalçalarınızdaki gerginlik ve gevşeme halleri arasındaki farka dikkat edin... ve bu serbest bırakma hissine devam edin... ve kalçalarınızın daha da gevşemesine izin verin...

Şimdi de bacaklarınızdaki kaslar... bu kasları bacaklarınızı düzleştirerek ve ayaklarınızı baldırlarınızı gerecek biçimde yere doğru eğerek gerebilirsiniz... şimdi bacaklarınızı olabildiğince düz tutun ve ayaklarınızı yere doğru eğin... daha sert... iyice sert... bacaklarınızdaki gerginliği hissedin... devam edin... ve yavaş̧a gevşeyin... bacaklarınızı gevşetin... ve tüm gerginliğin kaybolmasına izin verin... bacaklarınızda hiçbir gerginlik yok... kaslarınızdaki gevşemeyi ve rahatlamayı hissedin... ve bu serbest bırakma hissine devam edin... bacaklarınızı daha derince gevşemeye bırakın... ve tüm bedeninizde bu hissi duyumsayın... tüm kaslarınızı gevşek ve rahatlamış bırakmaya devam edin... bacaklarınızda, yüzünüzde, omuzlarınızda, kollarınızda hiçbir 
gerginlik yok... rahatça nefes alıp veriyorsunuz... tüm kaslarınız gevşek ve rahat... çaba harcamayın... hiçbir gerginlik yok... serbest bırakma hissine devam edin...

Şimdi, bedeninizdeki rahatlığı sürdürerek, size keyif verecek bir şeyi hayal etmeye çalışın... Sizi rahatlatacak bir durum... çok hoşunuza gidecek bir durum... hayal edebildiğiniz kadar canlı hayal edin... huzurlusunuz... sakinsiniz... ve rahatlayabildiğiniz kadar rahatsınız... bunu yaşayın... hiçbir sorun yok... hiçbir gerginlik yok... yalnızca gevşemenin keyfine varın... çok hoş ... tamamen huzurlu... bu birkaç dakikalık rahatlamadan zevk alın... (3 dakika)

Ve şimdi dörtten geriye doğru saymaya başlayacağım... her sayıda daha fazla uyanacaksınız. Ben bire geldiğimde, gözlerinizi açıp, uyanık bir biçimde oturacak ve çok canlı ve gevşemiş olacaksınız. Her sayıda gözlerinizi açmaya daha yakın olacaksınız. Dört... hoşlandığınız durumdan ayrılıyorsunuz. Üç... tekrar bu odadasınız. Uzanıyorsunuz. Nerede olduğunuzu biliyorsunuz. İki... Gözlerinizi açmaya hazırlanın. Gözlerinizi açınca ne göreceğinizi düşünün. Bir... gözlerinizi açın. Derin bir nefes alın odadaki nesnelere odaklaşın. Derin nefesler almaya devam edin. Hazır olduğunuzda, bacaklarınızı ve omuzlarınızı gerin. devam edin.

Şimdi ayağa kalkın ve gerinin. Derin nefesler alın. Şimdi, rahatladığınızı bilerek günlük etkinliklerinize

\section{Değerlendirme}

\section{Etkinlik}

Lider, katılımcılar aşağıdaki soruları sorar.

- Ne yaşadınız?

- Kaslarınızı gevşetebildiniz mi?

- Kaslarınızı gevşettikten sonra kendinizi nasıl hissettiniz?

Grup üyelerinin kas gevşeme egzersizlerinden nasıl yararlanabileceklerini ve kas gevşeme egzersizinden sonra kendilerini nasıl hissettikleri konusunda cevaplar verecekleri beklenmektedir. 